\title{
Employee Commitment in MNCs: Impacts of Organizational Culture, HRM and Top Management Orientations*
}

\author{
Sully Taylor, Orly Levy, Nakiye A. Boyacigiller, and Schon Beechler \\ International Journal of Human Resource Management. 19(4): 501-528.
}

Cite as follows: Taylor, S., O. Levy, N. A. Boyacigiller, \& S. Beechler (2008). Employee commitment in MNCs: Impacts of organizational culture, HRM and top management orientations. International Journal of Human Resource Management. 19(4): 501-528.

\footnotetext{
* This article contains material that is based upon work supported by the National Science Foundation under Grant No. 0080703. Any opinions, findings, and conclusions or recommendations expressed in this material are those of the authors and do not necessarily reflect the views of the National Science Foundation. The authors would also like to thank their home institutions for their support, and particularly the San Jose State Foundation and Lan Duong. In addition, they would like to thank Richard Osborne, Yiftach Gordoni, colleagues at ION, C7, the Academy of Management and the Academy of International Business for their earlier comments.
} 
This is the version of the article accepted for publication in The International Journal of Human Resource

Management published by Taylor and Francis doi:10.1080/09585190801953491

Accepted version downloaded from SOAS Research Online: http://eprints.soas.ac.uk/31984

\title{
Employee Commitment in MNCs: Impacts of Organizational Culture, HRM and Top Management Orientations
}

\begin{abstract}
This paper examines the impact of organizational culture and HRM system on employee commitment of core employees in multinational companies (MNCs). In addition, it identifies two top management team orientations - global orientation and geocentric orientation - that are seen as contributing uniquely to employee commitment in international firms. We found strong overall support for the model. The results also suggest that High Performance Work Practices have a positive impact on commitment regardless of national origin of the MNC.
\end{abstract}

Keywords: employee commitment; global mindset; high performance work practices; international management; organizational culture 
This is the version of the article accepted for publication in The International Journal of Human Resource Management published by Taylor and Francis doi:10.1080/09585190801953491

Accepted version downloaded from SOAS Research Online: http://eprints.soas.ac.uk/31984

\section{INTRODUCTION}

Organizational commitment in multinational corporations (MNCs) is a topic of growing importance to scholars and practitioners alike. First, firms increasingly disperse critical assets from R\&D to technologically complex manufacturing - to the global location that serves as the best platform for carrying them out (Bartlett and Ghoshal, 2000). These affiliates, and the employees working in them, are thus acquiring greater strategic importance in the MNC's global success. These employees' identification with the firm and willingness to work hard on its behalf are becoming crucial (Guest and Conway, 1997; Reade, 2001). Second, growing international competition means that MNCs must optimize the performance of all their affiliates - the MNC must “...push towards upgrading the internal capability of its subsidiaries” (Reade, 2001:419). This push places additional pressure on the MNC to retain high performing employees wherever they are (Bae et al., 1998; Harvey et al., 1999). Third, MNCs are increasingly pushed by competitive forces to leverage the learning capability of their global networks (Bartlett and Ghoshal, 2000; Nohria and Ghoshal, 1997). Creation and transfer of knowledge largely depend on the willingness and commitment of employees to undertake the complex organizational tasks of coordination and communication necessary to leverage knowledge for competitive advantage (Kogut and Zander, 1996; Nahapiet and Ghoshal, 1998; Storey and Quintas, 2001).

In spite of these pressures to nurture stronger commitment in employees worldwide, MNCs face greater difficulty than purely domestic firms in creating and maintaining organizational commitment in employees. Organizational commitment, which has been defined as “...the relative strength of an individual's identification with and involvement in a particular organization" (Mowday, Porter \& Steers, 1982: 27), is fostered when employees perceive that they are treated fairly and are valued for their contributions, when important promises have been met by the 
This is the version of the article accepted for publication in The International Journal of Human Resource Management published by Taylor and Francis doi:10.1080/09585190801953491

Accepted version downloaded from SOAS Research Online: http://eprints.soas.ac.uk/31984

organization, and when employees can trust the organization (Allen et al., 2003; Aquino et al., 1997; Gould-Williams, 2003; Guest and Conway, 1997; Wayne et al., 2002). Organizational commitment can also be enhanced through nurturing identification and involvement with the organization's goals and values (Meyer and Allen, 1991).

These conditions for creating commitment may be difficult to achieve in MNCs. Cultural diversity leads to differences in what employees expect from their work experiences, resulting in different perceptions of fair treatment (Kabanoff, 1997; Laurent, 1983) and hence different interpretations of whether promises are kept and contributions valued (Tsui et al., 1995), which can lead to lower trust and commitment (Gould-Williams, 2003). Cultural diversity can also hinder the development of social cohesion between employees (Buckley and Casson, 1998). Geographic dispersion makes the task of communicating a unifying vision and set of values more difficult, thus lowering organizational identification. In addition, geographic distance from the main power centers of the MNC can cause a sense of low involvement and attendant disaffection among employees. Located in overseas affiliates, employees are often far from the center of power and decision making, and hence may feel it is difficult to have an impact on the company commiserate with their knowledge and capabilities. Finally, turbulent changes in the global environment (Dessler, 1999) can create abrupt organizational changes in MNCs that undermine the sense of firm stability that supports a sense of trust and identification with firm goals. In short, while MNCs need to engender organizational commitment in employees in order to enhance overall firm performance, the unique challenges of operating globally make the achievement of this goal much more difficult than in domestic firms. It is thus imperative for top managers of MNCs to ask themselves what they can do organizationally to increase the commitment of their employees worldwide. 
This is the version of the article accepted for publication in The International Journal of Human Resource Management published by Taylor and Francis doi:10.1080/09585190801953491

Accepted version downloaded from SOAS Research Online: http://eprints.soas.ac.uk/31984

In this article we focus on the creation of organizational commitment in employees in MNCs. We analyze the role that the human organization plays, looking specifically at the impact of organizational culture and HRM on fostering organizational commitment in MNCs. Another part of the human organization we examine is two top management attitudes and policies unique to MNCs, which we call top management team orientations for simplicity, which can heighten employee commitment. We focus in this article on the commitment of core employees, who are more likely to be important to knowledge creation and sharing, and whose skills are most important to retain (Lepak and Snell, 2002). We test the hypotheses we derive from this analysis on a sample of 1664 employees in 39 subsidiaries of $10 \mathrm{MNCs}$.

Figure 1 presents the model of the human organization and commitment in MNCs tested in the current study. According to the model, in MNCs two fundamentals of the human organization — organizational culture and human resource management (HRM) —affect employees' commitment directly as well as indirectly through top management team orientations. As will be explained in the next section we focus here on two critical aspects of organizational culture for MNCs: shared sense of mission and adaptability. The top management team orientations - global orientation of top management and geocentric orientation — in turn affect organizational commitment directly. We first discuss organizational culture and HRM and consider their direct effects on commitment. Second, we consider the relationships between organizational culture and HRM on the one hand and top management team orientations on the other. Finally, we examine the relationships between these orientations and commitment. We then present the results of our empirical research. The findings provide strong support for the model overall, including the unique contribution of the two top management team orientations, global orientation of top managers and geocentric orientation, to creating commitment among employees in MNCs. 
This is the version of the article accepted for publication in The International Journal of Human Resource Management published by Taylor and Francis doi:10.1080/09585190801953491

Accepted version downloaded from SOAS Research Online: http://eprints.soas.ac.uk/31984

\section{THEORETICAL BACKGROUND}

Organizational commitment is defined as an attitude toward the organization manifested as identification with organizational goals, willingness to exert effort on behalf of the organization, and a strong desire to maintain membership in the organization (Mowday et al., 1979). In spite of some critiques (Swailes, 2002), this attitudinal definition of organizational commitment is the most widely validated and used in previous research. Many factors affecting commitment formation have been studied, including personal characteristics (e.g., educational background, gender), job characteristics (e.g., feedback), work experiences (e.g. group attitudes), and organizational characteristics (e.g. HR practices) (Gould-Williams, 2003; Mowday et al., 1979). In this study, while acknowledging the effects of the first three types of variables on commitment formation, we focus on the last category of organizational characteristics as this is the level that top managers in MNCs can affect and shape most strongly across the global network.

\section{Organizational Culture, HRM, and Commitment}

At the most general level, our model suggests (Figure 1) that organizational culture and the HRM system co-constitute the fundamentals of the human organization in MNCs, affecting employees' commitment both directly and indirectly.

Organizational culture. Organizational culture has recently been put forward as an understudied factor in nurturing organizational commitment (Lok and Crawford, 2001), and has been partially addressed empirically in studies by McCaul, Hinsz, and McCaul (1995) and Mueller, Wallace and Price (1992). Organizational culture is defined as "a system of shared values (that define what is important) and norms that define appropriate attitudes and behaviors for organizational members (how to feel and behave)" (O'Reilly and Chatman, 1996). Organizational values and norms govern the dual processes of external adaptation and internal integration and 
This is the version of the article accepted for publication in The International Journal of Human Resource Management published by Taylor and Francis doi:10.1080/09585190801953491

Accepted version downloaded from SOAS Research Online: http://eprints.soas.ac.uk/31984

define the way things are done in the organization (Schein, 1985). In MNCs, the complexity and dynamism of the global environment make external adaptation more urgent and internal agreement on goals more difficult for MNCs than for domestic firms. Given the context in which MNCs compete, in this article we focus on two organizational cultural dimensions: mission and adaptability (Denison and Mishra, 1995). ${ }^{1}$ Furthermore, we will look at affiliate level organizational cultures, as subcultures have been postulated to be at least as important as organizational culture to fostering employee commitment. Indeed, Lok and Crawford's study (2001) provides support for looking at subcultures within the total organization.

Mission. A strong sense of mission and a widely-shared and well-communicated vision is the "glue" that holds the company together, providing meaning and direction to organizational members (O'Reilly and Chatman, 1996). A sense of mission provides a stable point of reference and defines the appropriate course of action for the organization and its members (Denison and Mishra, 1995). Clarifying and communicating mission is considered one of the requirements for fostering employee commitment, because "the mission provides a focus to which employees can commit" (Daft, 1992; Dessler, 1999). In MNCs, a strong sense of mission is especially important as it can create a sense of common destiny, unifying far-flung employees working across borders and time zones to achieve organizational goals. A sense of mission focuses employees' attention and efforts around a set of superordinate goals (Collins and Porras, 1997; Dessler, 1999; Kanter, 1972; Virtanen, 2000), which can help shape individual work goals and roles. Differences of perception among global employees of appropriate work roles and behaviors are more likely than in a domestic setting. The shared mission in a MNC may affect commitment by clarifying roles and making daily work more goal oriented among employees who are geographically dispersed and culturally diverse. Indeed, empirical research has found that role clarity and meaningful tasks lead 
This is the version of the article accepted for publication in The International Journal of Human Resource Management published by Taylor and Francis doi:10.1080/09585190801953491

Accepted version downloaded from SOAS Research Online: http://eprints.soas.ac.uk/31984

to higher commitment in employees (Gould-Williams, 2003; Howell and Dorfman, 1986).

Therefore, we suggest that in MNCs, employees' perception of a strong mission will be positively related to employee commitment:

Hypothesis 1a In MNCs, employees' perception of the MNC's mission will be positively related to employee commitment.

Adaptability. In today's dynamic competitive environment, adaptability is especially critical to MNC success. The adaptability dimension captures the capacity of the organization to flexibly reorient itself toward the external environment and create change. It reflects the degree to which the organization's culture encourages a customer focus, risk taking, learning from mistakes, and the ability to create change (Fey and Denison, 2003). These values and norms facilitate organizational adaptation to changing external circumstances by creating a flexible and dynamic work environment that gives employees latitude of action to take initiatives and risks and to engage with customers. This leads to a 'fit' between the organization's culture and the ever-changing global environment in which it operates, which promotes greater sense of managerial support for the behaviors employees feel they must exhibit for the firm to be successful. Previous empirical research suggests that these characteristics of autonomy and risk taking are especially important in engendering commitment of employees (Sigler and Pearson, 2000).

Hypothesis $1 \mathrm{~b} \quad$ In MNCs, employees' perception of the MNC's adaptability will be positively related to employe commitment.

The HRM System. The HRM system encompasses the HR philosophy or architecture as well as practices that govern the organizational approach to managing its human assets (Becker and Huselid, 1998; Pfeffer, 1996). We utilize a High Performance Work Practices (HPWPs) framework to examine the underlying HRM philosophy of MNCs. These are sometimes called 
This is the version of the article accepted for publication in The International Journal of Human Resource Management published by Taylor and Francis doi:10.1080/09585190801953491

Accepted version downloaded from SOAS Research Online: http://eprints.soas.ac.uk/31984

high commitment practices. HPWPs include such practices as “...rigorous recruitment and selection procedures, performance-contingent incentive compensation systems, management development and training activities linked to the needs of the business, and significant commitment to employee involvement" (Becker and Huselid, 1998: 55).

While the exact nature and extent of the effect of HPWPs is still under debate and investigation (Harley, 2002; Ramsay et al., 2000; Youndt et al., 1996), there is some evidence to suggest that HPWPs do in fact positively affect employee attitudes as well as organizational performance (Becker and Huselid, 1998; Huselid, 1995; Whitener, 2001). Both bundles or sets of HPWPs as well as individual HR practices have been investigated for their effects on employee commitment (Arthur, 1994; MacDuffie and Kochan, 1995). There is growing evidence for the link between HPWPs bundles and commitment (Gould-Williams, 1998; Guest and Conway, 1997; Iles et al., 1990). In addition, looking at individual HR practices, Tsui et al. (Tsui et al., 1997) discovered that employees developed greater affective commitment to employers who provided high levels of training and employment security. With regard to firm performance, Becker and Huselid (1998:10) found that a set of HPWPs “...has an economically and statistically significant positive effect on firm performance", although it must be pointed out that some doubt as to the order of causality has been raised by recent research (Wright et al., 2005).

While most previous research has documented the positive impact of HPWPs in domestic firms, we argue that HPWPs also positively affect employee commitment in MNCs by reducing the potential alienation caused by geographic and cultural distance. A key advantage of HPWPs is that 'the employee working under such an HRM system (will) positively and affectively commit themselves to the aims and values of their employers...' (Hope, 1994). The HPWPs are posited to develop psychological links between organizational and employee goals, which leads to 
This is the version of the article accepted for publication in The International Journal of Human Resource Management published by Taylor and Francis doi:10.1080/09585190801953491

Accepted version downloaded from SOAS Research Online: http://eprints.soas.ac.uk/31984

'committed employees who can be trusted to use their discretion to carry out job tasks in ways that are consistent with organizational goals' (Arthur, 1994: 672). Thus, MNCs that adopt and implement a HPWPs approach to HR are more likely to engender commitment in their employees.

Hypothesis 2 In MNCs, employees' perception of the adoption of HPWPs will be positively related to employee commitment.

\section{Organizational Culture, HPWPs, and Top Management Team Orientations}

As suggested earlier, while the cultural dimensions of mission and adaptability and the HRM system are important, in MNCs there are unique factors that also engender commitment. Thus, the effect of organizational culture and mission is also mediated through the top management teams' orientations. These top management team orientations signal to employees that the organization is providing the support they need to successfully operate globally. Support is shown by instituting geocentric policies that reward the employees fairly for their contributions and maximize the effective use of talent worldwide, and by creating the perception that the firm will be successful and able to fulfill its promises because top management is appropriately oriented towards the global arena. We propose that the effect of organizational culture in MNCs goes beyond commitment to influence the development of global orientation. Similarly, in addition to its direct effect on commitment, the significance of a HPWP system in MNCs stems from its influence on the adoption of geocentric staffing policies.

Organizational culture and global orientation. There has been a growing recognition that successful managers in MNCs are those who develop the 'mindset' required to understand the complex global environment (Govindarajan and Gupta, 1998; Kanter, 1994); and to balance the conflicting and competing demands of their businesses, operations, and geographies (Evans and Doz, 1992; Murtha et al., 1998). Senior managers must develop a global orientation, defined as an 
This is the version of the article accepted for publication in The International Journal of Human Resource Management published by Taylor and Francis doi:10.1080/09585190801953491

Accepted version downloaded from SOAS Research Online: http://eprints.soas.ac.uk/31984

awareness and knowledge of global competitive dynamics and changes, coupled with the development of structures and processes to successfully confront these changes. ${ }^{2}$

While global orientation is an individual level construct, organizational culture can have a profound effect on the development of the global orientation of senior managers. Culture can be conceived as an interpretative system that structures managerial attention, knowledge, and action (Daft and Weick, 1984). Thus, in MNCs organizational culture that is characterized by a marked emphasis on the external environment, reflected and exemplified by a strong sense of mission and high adaptive capacity, will tend to orient managers toward the global environment and foster a global orientation. This is consistent with results of longitudinal research by Murtha, Lenway \& Bagozzi (Murtha et al., 1998), who found that global mindset follows global strategy. A strong cultural emphasis on adaptability will also engender a global orientation in top management. In MNCs oriented to responding to external changes and to customers, and taking risks to do so, the top managers will be encouraged by these company values and norms to be aware of external global developments, and their global orientation will therefore increase. Therefore we offer two hypotheses:

Hypothesis 3a In MNCs, employees' perception of mission will be positively related to the perceived global orientation of top management.

Hypothesis $3 \boldsymbol{b} \quad$ In MNCs, employees' perception of adaptability will be positively related to the perceived global orientation of top management.

HRM and geocentric orientation. The final top management orientation we discuss is a geocentric orientation to HRM policies. In contrast to an ethnocentric HRM policy that assigns only home country nationals to top level management positions, a geocentric HRM policy staffs top management positions, both at home and overseas, from a global pool of workers based on 
This is the version of the article accepted for publication in The International Journal of Human Resource Management published by Taylor and Francis doi:10.1080/09585190801953491

Accepted version downloaded from SOAS Research Online: http://eprints.soas.ac.uk/31984

individual capabilities and qualifications (Kobrin, 1994; Perlmutter, 1969). Thus, a geocentric HRM policy seeks the best people for key positions throughout the corporation, irrespective of nationality.

We expect that a geocentric orientation and hence a geocentric staffing policy will be evident in firms that have adopted a HPWPs set of practices or approach. Contingency or fit theory suggests that the two 'pieces' — the underlying HRM approach of the firm and its global staffing policy — must fit in order to enhance organizational success (Nadler and Tushman, 1980), an idea reinforced by strategic HRM theorists and researchers (Butler et al., 1991; Cappelli and Singh, 1992; Wright and McMahan, 1992). Geocentrism and HPWPs are at their core similar approaches to managing people. Geocentrism is predicated on an open selection process that is merit - rather than nationality - based. Similarly, a key aspect of HPWPs is an emphasis on rigorous recruitment and selection procedures and a performance based reward system (Becker and Huselid, 1998).

MNCs that have adopted a HPWP approach will thus be more likely to install a geocentric staffing policy as it is most in keeping with the merit based staffing system that seeks to optimize the selection of the best candidate for a job. We therefore hypothesize that:

Hypothesis 4 In MNCs, employees' perception of the adoption of HPWPs will be positively related to perceived geocentric orientation.

\section{Global Orientation of Top Managers and Geocentric Orientation}

Building on our previous discussion of global orientation of top managers, much of the literature on the defining features of effective global managers finds that they are characterized by an openness to diversity, particularly cultural diversity (Adler and Bartholomew, 1992; Estienne, 1997; Maznevski and Lane, 2004; Rhinesmith, 1992; Rhinesmith, 1993; Rhinesmith, 1996). These authors emphasize that top managers with a global orientation will make decisions that are 
This is the version of the article accepted for publication in The International Journal of Human Resource Management published by Taylor and Francis doi:10.1080/09585190801953491

Accepted version downloaded from SOAS Research Online: http://eprints.soas.ac.uk/31984

independent of assumptions from any one culture (Maznevski and Lane, 2004), which presumably extends to personnel selection decisions. Managers with this orientation will embrace the cultural diversity of their global workforce and seek to use it to competitive advantage. As Kobrin (1994) argues, a geocentric IHRM system is one of the key manifestations of a global orientation in the top management team (Kobrin, 1994). Consequently, it can be argued that a higher level of perceived global orientation among top managers will be associated with a higher level of geocentric orientation, leading us to the following hypothesis:

Hypothesis 5 In MNCs, employees' perception of global orientation in top management will be positively related to perceived geocentric orientation.

\section{Top Management Team Orientations and Organizational Commitment}

While organizational culture and the HRM system are important for engendering commitment, we suggest that their effect is also mediated through top management team orientations. Thus, we posit that in MNCs these top management attitudes and policies affect employees' commitment directly.

Global Orientation. In MNCs, top managers with a global orientation face, rather than avoid, the challenges associated with globalization. Arguably, employees will have more confidence and trust in top managers with a global orientation, whom they perceive as capable of guiding the MNC through business challenges. Drawing on social exchange theory (Blau, 1964) and recent research on the relationship between perceived organizational support (POS) and trustin-management (Whitener, 2001), we predict that employees' confidence in their top managers will foster acceptance of and commitment to organizational goals (Brewer, 1994; Kouzes and Posner, 2002; Tsui et al., 1995) as well as a desire to stay with a "global winner" organization. Therefore, we hypothesize that: 
This is the version of the article accepted for publication in The International Journal of Human Resource

Management published by Taylor and Francis doi:10.1080/09585190801953491

Accepted version downloaded from SOAS Research Online: http://eprints.soas.ac.uk/31984

Hypothesis 6 In MNCs, employees' perception of the global orientation of top managers will be positively related to employee commitment.

Geocentric Orientation. Finally, a geocentric orientation is likely to engender commitment because it communicates to employees that the company values their contribution and provides significant career opportunities regardless of nationality. HR practices that signal that the organization values employees and provides non-discriminatory growth and promotion opportunities are likely to increase the feeling that the employer cares about them and values their contributions (Allen et al., 2003; Wayne et al., 1997). Drawing on social exchange theory (Blau, 1964) and the norm of reciprocity (Gouldner, 1960), researchers posit that “...greater perceived organizational support (POS) is expected to result in greater affective attachment and feelings of obligation to the organization" (Allen, Shore \& Griffeth, 2003: 99) and leads to higher levels of commitment (Allen et al., 2003; Wayne et al., 2002). Thus, we suggest that a perceived geocentric orientation among top managers can engender employee commitment through fostering a greater sense of POS. This leads to the following hypothesis:

Hypothesis 7 In MNCs, employees' perception of a geocentric orientation will be positively related to employee commitment.

\section{METHODS}

\section{Sample}

The sample for this study consists of 1664 employees with higher education (college degree and above) who can be considered core knowledge employees (Lepak and Snell, 2002). Formal level of education is a good proxy of individual human capital and individuals with more years of schooling usually have more formal knowledge and professional expertise as well as the potential to develop superior skills and capabilities. Therefore, these employees are likely to create the most 
This is the version of the article accepted for publication in The International Journal of Human Resource Management published by Taylor and Francis doi:10.1080/09585190801953491

Accepted version downloaded from SOAS Research Online: http://eprints.soas.ac.uk/31984

valuable knowledge for the MNC. The sample includes 968 (58.2\%) respondents with a college degree, 256 (15.4\%) who have some graduate work, and 440 (26.4\%) who have a graduate degree. The sample participants are employed by ten MNCs headquartered in Australia, Israel, Japan, Mexico, and the U.S: 620 (37.3\%) of the sample participants are employed by Australian MNCs, $181(10.9 \%)$ by an Israeli MNC, $290(17.4 \%)$ by Japanese MNCs, 127 (7.6\%) by a Mexican MNC, and $446(26.8 \%)$ by American MNCs. The sample includes 1143 (68.7\%) males, and 521 females (31.3\%) and 636 (38.2\%) employees work in the headquarters and 1028 employees (61.8\%) work in 39 overseas affiliates located in a total of twelve countries (Australia, Brazil, Japan, New Zealand, the Netherlands, Philippines, Singapore, Spain, Switzerland, Thailand, UK, USA) ${ }^{3}$.

Data were collected using a questionnaire survey distributed in both the headquarters and in overseas affiliates of each of the companies. The original English-language questionnaire was translated into Dutch, German, Hebrew, Japanese, Portuguese, and Spanish by professional translators and then back-translated and checked for equivalency to the English original. We used native language questionnaires in all locations, except for the Philippines and Thailand where questionnaires were distributed in English as English was the common language used within the affiliates and all respondents spoke and read English.

\section{Analytic Strategy}

The principal analysis consisted of confirmatory latent-variable structural equation modeling using the EQS 5.6 program (Bentler, 1995). The structural equation modeling technique provides a simultaneous estimation of a measurement model and a structural model. The measurement portion of the model was assessed first in isolation from the influences of the structural part. In adopting this analytic strategy, we closely followed Anderson and Gerbing's approach (Anderson and Gerbing, 1988) to structural equation models analysis (Boomsma, 2000; 
This is the version of the article accepted for publication in The International Journal of Human Resource Management published by Taylor and Francis doi:10.1080/09585190801953491

Accepted version downloaded from SOAS Research Online: http://eprints.soas.ac.uk/31984

Cohen et al., 1990; Hair et al., 1995; Kline, 1998; Medsker et al., 1994; Raykov et al., 1991;

Schumacker and Lomax, 1996; Shook et al., 2004).

\section{Measures}

All measures included in the model were subjected to a two-step evaluation. In Step 1, each scale was evaluated in isolation through confirmatory factor analysis in order to examine its factorial and convergent validity. ${ }^{4}$ In Step 2, the entire measurement model was evaluated, allowing the constructs in the structural portion to co-vary freely without constraints. The overall fit and the psychometric properties of each latent variable were assessed in the same manner as in the previous step. The results from this step provide indications for the convergent and discriminant validity of the latent variables in the model. We first describe the measures used in this study and the results of Step 1. We then report the results of the second evaluation step.

Organizational commitment. Organizational commitment was measured using the nineitem short form of the Organizational Commitment Questionnaire (OCQ) developed by Mowday, Steers, and Porter (1979) (Mowday et al., 1979). We chose the Mowday et al. (Mowday et al., 1979) inventory due to the diverse multi-cultural setting of this study. As the majority of commitment studies have been conducted in North America, the cross-cultural generalizability of commitment measures is a significant methodological issue. The Mowday et al. (Mowday et al., 1979) inventory, however, has been widely used in cross-cultural research on commitment and its cross-cultural generalizability is established (Harrison and Hubbard, 1998; Luthans et al., 1985; Peterson et al., 2003; Yousef, 2000; Yousef, 2003). On the other hand, the cross-cultural generalizability of less parsimonious commitment measures is still in question, as several studies conducted outside North America did not replicate the multidimensionality of commitment measures. For example, a recent meta-analysis of commitment studies that used the Allen and 
This is the version of the article accepted for publication in The International Journal of Human Resource Management published by Taylor and Francis doi:10.1080/09585190801953491

Accepted version downloaded from SOAS Research Online: http://eprints.soas.ac.uk/31984

Meyer's (Allen and Meyer, 1990) three-component measure of commitment revealed that the correlations among the affective and normative components is even higher in studies conducted outside North America (Meyer et al., 2002).

In Step 1, the OCQ scale was subjected to confirmatory factor analysis in order to assess its factorial and convergence validity. There are two plausible models that can describe the factorial structure of this instrument: a three correlate factors model and a one-factor model (Mowday et al., 1979). Both models reached acceptable fit level, Although the one-factor model had a significantly worse fit $\left(\Delta s-b \chi^{2}(3)=134.24, p<.001\right)$ along with worse performance on the other fit indices $(\Delta \mathrm{SRMSR}=.014, \Delta \mathrm{CFI}=-.022, \Delta \mathrm{NFI}=-.023)$, it was more parsimonious $(\Delta \mathrm{PCFI}=.064$, $\triangle \mathrm{PNFI}=.063$ ), and therefore preferred over the three- factor model (see Table 4). Evidence for the convergence validity of this scale is shown in Table 5.

Organizational culture. Measures of organizational culture were based on scales drawn from the Denison Organizational Culture Survey (Denison et al., 2000; Denison and Mishra, 1995; Denison and Neale, 1996). This instrument is explicitly designed to measure relatively visible and observable aspects of organizational culture — practices and behaviors — rather than "invisible" and not directly observable aspects of culture such as values and basic assumptions. The survey items ask respondents to indicate agreement/disagreement with statements describing "the way things are usually done" at the business or shared services unit where they currently work on a five-point Likert scale. Focusing respondents' attention on their immediate organization ensures that organizational culture rather than national culture is the focal point, an important consideration in cross-cultural research.

In Step 1, the two scales measuring culture—mission and adaptability—were subjected to confirmatory factor analyses in order to assess their factorial and convergence validity. The 
This is the version of the article accepted for publication in The International Journal of Human Resource Management published by Taylor and Francis doi:10.1080/09585190801953491

Accepted version downloaded from SOAS Research Online: http://eprints.soas.ac.uk/31984

factorial validity of the scales was tested by comparing two feasible models: a second order factor model, containing three first-order factors, and a one-factor model. Following the results of validation research on the Denison Organizational Culture Survey (e.g., (Denison et al., 2000)), the second-order structure is hypothesized to be the valid one. In the mission scale, both second order factor and one-factor were found to fit the data well in all aspects (see Table 4). Although the second-order factor model had a significantly better fit $\left(\Delta s-b \chi^{2}(3)=70.88, p<.001\right)$, the improvement of the other fit indices was somewhat low $(\Delta \mathrm{SRMSR}=-.006, \Delta \mathrm{CFI}=.011, \Delta \mathrm{NFI}=.011)$ and it was less parsimonious $(\triangle \mathrm{PCFI}=-.074, \Delta \mathrm{PNFI}=-.074),(\Delta \mathrm{SRMSR}=-.006, \Delta \mathrm{CFI}=.015$, $\Delta \mathrm{NFI}=.013)$. Therefore, we choose the one-factor model for the mission scale. In the adaptability scale, the second-order factor model demonstrated an acceptable fit to the data whereas the onefactor model did not reach an acceptable fit on any index (see Table 4). Therefore, we choose the second-order factor model for the adaptability scale. Evidence for the convergence validity of the organizational culture scales is shown in Table 5.

HPWPs. We have drawn on previous research in the area of HPWP to examine this aspect of the model (Arthur, 1994; Becker and Gerhart, 1996; Delaney and Huselid, 1996; Delery and Doty, 1996; Huselid, 1995; MacDuffie, 1995; Pfeffer, 1998), and to create measures of HPWP (see Appendix A). The four major sources for measures of HPWPs were Pfeffer, (1998), Delery and Doty (1996), MacDuffie (1995) and Huselid (1995) as these cover the most significant HPWP domains and yet are brief enough to be included in a survey questionnaire (Delery and Doty, 1996; Huselid, 1995; Pfeffer, 1998). Based on a seven-point Likert scale, respondents were asked to indicate agreement/disagreement with 18 statements describing human resource practices common to the business unit where they currently worked. 
This is the version of the article accepted for publication in The International Journal of Human Resource Management published by Taylor and Francis doi:10.1080/09585190801953491

Accepted version downloaded from SOAS Research Online: http://eprints.soas.ac.uk/31984

In Step 1, the factorial validity of the HPWPs instrument was tested by comparing two feasible models: a second order factor structure containing three first-order factors and a one-factor model. The second-order factor model demonstrated an acceptable fit to the data, while the onefactor model did not reach an acceptable fit level on any index (see Table 4). Thus, the secondorder factor model was found to be a better specified model. Additional evidence for the convergence validity is shown in Table 5. Discriminant validity of the first-order factors was established based on the superiority of the second-order model over the simpler one-factor model.

Global orientation. Measures of top managers' global orientation were based on previous research by Ashkenas et al. (Ashkenas et al., 1995). Respondents were asked to indicate agreement/disagreement on a seven-point Likert scale with five statements describing the global orientation of top managers in the business unit where they currently work. A saturated one-factor model was fitted in order to examine the convergence validity of this scale (see Table 5).

Geocentric orientation. A geocentric orientation was measured using a four item scale developed by Kobrin (Kobrin, 1994). Respondents were asked to indicate agreement/disagreement with statements on a seven-point Likert scale regarding the impact of nationality in general and of headquarters nationality in particular on selection and promotion of managers. A one-factor structure demonstrated an acceptable fit to the data (see Table 4). Evidence for the convergence validity of this scale is also shown in Table 5.

Control variables. The following four individual level variables were included as controls. Gender was coded 0 for female and 1 for male. Gender has been found to have an inconsistent relationship with commitment (Mathieu and Zajac, 1990; Meyer et al., 2002). Tenure was measured in employment years with the MNC. Tenure has been found to have a weak but positive relationship with commitment (Meyer et al., 2002). Cosmopolitan background was measured 
This is the version of the article accepted for publication in The International Journal of Human Resource Management published by Taylor and Francis doi:10.1080/09585190801953491

Accepted version downloaded from SOAS Research Online: http://eprints.soas.ac.uk/31984

using 3 dichotomous Yes/No questions derived from Birnbaum and Wong (1985) and one openended question ("How many foreign languages do you speak well?") that was recoded dichotomously (None $=0 ; 1$ or more languages $=1)($ Birnbaum and Wong, 1985). The score for this index was a sum composite score ranging from 0 to 4 , with a higher score indicating a more cosmopolitan background. Greater cosmopolitanism could be associated with greater comfort in working in a global firm, and hence affect commitment. Finally, we used a two-category schema to control for home country-host country nationality of employees as members of the 'out-group' (host country employees) might feel less committed. Home country nationality was coded as 1 and host country nationality as 0 . In addition, we used a dummy variable to control for the parent nationality of the firm: firms headquartered in Anglo cluster countries (i.e., Australia, US) were coded as 1; all other firms were coded as 0 (Ronen and Shenkar, 1985).

In Step 2, the measurement sub-model fit to the data, which is the highest fit possible for any full model, was found acceptable, although somewhat low on the NFI index (s-b $\chi^{2}$ $(1071)=3724.31, \mathrm{p}<.001, \mathrm{SRMSR}=.042$, robust $\mathrm{CFI}=.918$, robust $\mathrm{NFI}=.889, \mathrm{~N}=1664)$ and was an indication for the discriminant validity of the scales in the model. The convergent validity of the scales was established based on the significance of all the loadings (all above .47), the composite reliabilities (all above .72), and the variance-extracted indexes that were all, with the exception of geocentrism (.40), found acceptable. The results from fitting the measurement model to the data, along with the disattenuated correlation between the constructs (corrected for unreliability), are shown in Table 2.

\section{Analyses}

The hypothesized structural model was tested by combining a simultaneous estimation and evaluation of the measurement and structural parts. This assessment, following Anderson and 
This is the version of the article accepted for publication in The International Journal of Human Resource Management published by Taylor and Francis doi:10.1080/09585190801953491

Accepted version downloaded from SOAS Research Online: http://eprints.soas.ac.uk/31984

Gerbing's approach (Anderson and Gerbing, 1988), was made via estimation and comparison of several theoretical alternative nested models. The models were compared following Mulaik's approach to fit evaluation (Carlson and Mulaik, 1993; Mulaik et al., 1989) in order to find the most plausible and parsimonious model that may be responsible for the observed data ${ }^{5}$. We considered multiple criteria to evaluate model fit based on various measures simultaneously (e.g., (Boomsma, 2000; Hair et al., 1995; Schumacker \& Lomax, 1996)). We evaluated and compared the models based on three fit indices: absolute fit indices ( $\chi^{2}$, SRMSR), incremental fit indices (CFI, NFI) and parsimony fit indices (PCFI, PNFI) (Boomsma, 2000; Hu and Bentler, 1998; Medsker et al., 1994). According to Mulaik's approach to fit evaluation (Carlson and Mulaik, 1993; Mulaik et al., 1989) more weight was put on model parsimony, so a model could be declared a better fitting model only if it also proved to have a more parsimonious fit, along with a significantly and descriptively better and acceptable fit.

The analyses were performed using a covariance matrix of the observed variables. In order to partial out the potential effect of the employee's background, five control variables were entered to the model as covariates and each of them were connected to all the latent variables. Due to deviation from normality of the observed variables, the estimation method chosen (maximum likelihood) was used with the robust correction for the $\chi^{2}$ index and the standard errors of the parameters estimators (Bentler, 1995; Boomsma, 2000; Byrne, 1994).

\section{RESULTS}

In order to gain a first impression of the relationships between the variables in the structural part of the model, a composite score for each variable was calculated as the mean of all its items. Table 1 presents the means, standard deviations, and zero-order correlations among all these 
This is the version of the article accepted for publication in The International Journal of Human Resource Management published by Taylor and Francis doi:10.1080/09585190801953491

Accepted version downloaded from SOAS Research Online: http://eprints.soas.ac.uk/31984

composite scores, along with a reliability index (Cronbach's alpha) on the main diagonal. As can be seen, there are large correlations among the latent variables (an estimated range between .30 to .70) and low correlations between the latent variables and the control variables, except parent country nationality, which demonstrate moderate correlations with the latent variables. It seems that the parameters relating the latent variables are needed in order to account for these large correlations, as hypothesized. A similar correlation pattern appears in Table 2, which presents disattenuated correlations between the variables after correcting for unreliability. Some of the correlations between the latent variables seem somewhat high, but evidence for discriminant validity obtained from the measurement model assessment supports the unique existence of these variables.

In testing the theoretical framework, we followed Anderson and Gerbing's two-step approach (Anderson and Gerbing, 1988) and fitted a hypothesized model and several nested models to the data, each representing different assumptions about the model parameters. The hypothesized model, representing the substantive model of interest, suggests that the organizational culture and HRM constructs affect commitment directly and indirectly through the top management team orientations. Two alternative models provided a base-line fit for assessment of the hypothesized model: the null model where all parameters relating the latent constructs are fixed to zero, and the measurement model that frees all the parameters relating the latent variables and have been assessed in detail in step 1 of the analysis. We also assessed five additional models that are more constrained than the hypothesized model, representing alternative theoretical perspectives. Table 3 presents the results from fitting the above models to the data.

According to the results presented in Table 3, the hypothesized model was found to be superior over the null model, adding significantly to the explanation of the relationships among the 
This is the version of the article accepted for publication in The International Journal of Human Resource Management published by Taylor and Francis doi:10.1080/09585190801953491

Accepted version downloaded from SOAS Research Online: http://eprints.soas.ac.uk/31984

latent variables $\left(\Delta \mathrm{s}-\mathrm{b} \chi^{2}(12)=3497.01, \mathrm{p}<.001\right)$ along with better descriptive fit indices

$(\Delta \mathrm{SRMSR}=-.159, \Delta \mathrm{CFI}=.108, \Delta \mathrm{NFI}=.14)$ and higher parsimony $(\Delta \mathrm{PCFI}=.09, \Delta \mathrm{PNFI}=.087)$. The hypothesized model demonstrated similar fit as that of the measurement model $(\triangle \mathrm{SRMSR}=0$, $\Delta \mathrm{CFI}=0, \Delta \mathrm{NFI}=-.001$ ), a better degree of parsimony even though subjected to more tests for potential disconfirmation $(\triangle \mathrm{PCFI}=.002, \triangle \mathrm{PNFI}=.003)$, and an acceptable fit to the data. This model also demonstrated superiority over the more constrained models. Thus, despite a very small significant lack of fit compared to the measurement model $\left(\Delta s-b \chi^{2}(3)=13.57, p<.01\right)$, the hypothesized model was found to be the most plausible and parsimonious of all the models tested. Figure 2 presents the parameter estimates for the hypothesized model.

Examining the standardized parameters estimators indicated 8 out of the 9 hypothesized relationships were significant and in the predicted directions when the control variables were accounted for (see Figure 2). Statistically significant parameter estimates were found for the paths between Adaptability $(\beta=.299, \mathrm{p}<.001)$ and HPWPs $(\beta=.374, \mathrm{p}<.001)$ to commitment, providing support for Hypothesis $1 \mathrm{~b}$ and Hypothesis 2 . The path between mission and commitment was not found to be significant $(\beta=.042, \mathrm{p}>.05)$. Thus H1a was not supported. Overall, the hypotheses relating the organizational culture and HPWPs constructs directly to commitment were partially supported. Hypotheses $3 \mathrm{a}$ and $3 \mathrm{~b}$, which positively relate mission (H3a) and adaptability (H3b) to global orientation, were supported as statistically significant parameter estimates were found for the paths between mission $(\beta=.515, \mathrm{p}<.001)$ and adaptability $(\beta=.235, \mathrm{p}<.001)$ to global orientation. HPWPs were found to have a significant positive effect on geocentric orientation $(\beta=.310, p<.001)$, supporting Hypothesis 4. Global orientation was found to have a positive significant effect on geocentric orientation $(\beta=.149, \mathrm{p}<.001)$, thus supporting Hypothesis 5. Overall, the organizational culture and HPWPs constructs were found to have a significant effect on at least one of the top 
This is the version of the article accepted for publication in The International Journal of Human Resource Management published by Taylor and Francis doi:10.1080/09585190801953491

Accepted version downloaded from SOAS Research Online: http://eprints.soas.ac.uk/31984

management team orientations. Hypothesis 6 and 7 were supported as statistically significant parameter estimates were found for the path between global orientation $(\beta=.082, \mathrm{p}<.05)$, geocentric orientation $(\beta=.080, \mathrm{p}<.01)$ and commitment. These findings support the hypothesized indirect effects from organization culture and HPWPs on commitment through top management team orientations. Finally, the correlations between mission, adaptability, and HPWPs were significant and positive (Mission-Adaptability: $\mathrm{r}=.839, \mathrm{p}<.001$; Mission-HPWP: $\mathrm{r}=.748, \mathrm{p}<.001$; AdaptabilityHPWP: $\mathrm{r}=.818, \mathrm{p}<.001)$. Two of the control variables were significantly related to commitment, above and beyond all other variables in the model: tenure and gender. Tenure was negatively related to commitment $(\beta=-.047, \mathrm{p}<.05)$, that is employees with longer tenure are less committed to the company. In addition, males were more committed to the company than females ( $\beta=.067$, $\mathrm{p}<.01)$. All other control variables did not reach significance.

The variables in the model were found to explain a sizeable amount of variance in commitment (60.6\%), and the percent of explained variance exceeds $30 \%$ for all the endogenous variables in the model. These findings support the majority of the hypotheses forming this model, and support for the plausibility of the omitted paths gained from comparing the final model to the measurement model.

\section{DISCUSSION}

This paper proposed a model that links the creation of employee commitment in MNCs, a key factor in both knowledge transfer and innovation and in creating cohesion among culturally diverse and geographically dispersed employees, to the human organization of the firm. The study tested whether the unique challenges facing MNCs requires particular top management team orientations in order to nurture employee commitment, in addition to the traditional mechanisms of 
This is the version of the article accepted for publication in The International Journal of Human Resource Management published by Taylor and Francis doi:10.1080/09585190801953491

Accepted version downloaded from SOAS Research Online: http://eprints.soas.ac.uk/31984

organizational culture and HRM. Empirical support of our model substantiates the importance of the human organization to employees' commitment in MNCs.

At the most general level, the results demonstrate that the two dimensions of organizational culture and the HRM system positively affect commitment. However, as the model suggests, the effect of traditional elements of the human organization in MNCs is partially mediated through top management orientations specific to international firms. Thus, one of the most significant findings of this research concerns the role top management team orientations play in facilitating a positive impact of the human organization on employee commitment in MNCs. Specifically, perception of a sense of mission indirectly affects commitment through its effect on global orientation of top management. Perception of a culture of adaptability, on the other hand, affects commitment strongly and directly, as well as indirectly through global orientation. The HRM system, measured in term of perceived presence of HPWPs, affects commitment directly and also indirectly through its effect on geocentric orientation. Perceived top management global orientation and geocentric orientation, in turn, positively impact employee commitment, although the effects are relatively small. The validity and generalizability of these results is strengthened by the control of a diverse set of demographic variables as well as nationality of parent company and of employees. This is clearly demonstrated by the significantly better fit of the model including the human organization and control variables over the alternative model containing only the control variables as predictors. These findings have implications for theories of the multinational firm, HRM and commitment.

This study draws on the theoretical view that as knowledge creating organizations, MNCs depend on the willingness and commitment of employees to undertake the complex organizational tasks of coordination and communication knowledge creation requires (Kogut and Zander, 1996). This coordination and communication must occur under conditions of complexity, 
This is the version of the article accepted for publication in The International Journal of Human Resource Management published by Taylor and Francis doi:10.1080/09585190801953491

Accepted version downloaded from SOAS Research Online: http://eprints.soas.ac.uk/31984

interdependence, and ambiguity that characterize much of the activities of MNCs (Doz and Prahalad, 1991; Hedlund, 1986; Nohria and Ghoshal, 1994; Nohria and Ghoshal, 1997). Under such conditions, organizational culture is a particularly effective and flexible integration, coordination, and control mechanism (Wilkins and Ouchi, 1983). Therefore, organizational culture plays a major role in enhancing the value-creating capacity of the multinational firm and its globally dispersed parts (Nohria and Ghoshal, 1997). The model we propose explicates the cognitive and attitudinal links between organizational culture on the one hand and value-creation capacity on the other hand. It suggests that the capacity of organizational culture to enhance the value-creation capacity of MNCs lies in its ability to foster the development of top management orientations, and to engender employees' commitment to organizational goals, both directly and indirectly. Specifically, the results suggest a sense of mission and a culture of adaptability, as perceived by an MNC's core employees, affects the global orientation of senior managers. Perceived global orientation of top management is in turn related to increased employee commitment. Thus part of the significance of organizational culture in the context of MNCs lies in its ability to structure the cognitive orientation of senior managers and to orient them toward the global environment. Finally, the results suggest that one aspect of organizational culture, adaptability, affects employees' commitment both directly and indirectly as well.

The implications of these findings are threefold. First, the importance of organizational culture in MNCs goes beyond providing integration. It also affects managerial cognition and action. Second, organizational culture also fosters normative integration by affecting employees' attitudes, specifically commitment to organizational goals. Finally, while organizational culture is important, its effect is partially mediated through top management orientations specific to MNCs. Thus, the findings suggest that MNCs cannot afford to rely solely on traditional elements to 
This is the version of the article accepted for publication in The International Journal of Human Resource Management published by Taylor and Francis doi:10.1080/09585190801953491

Accepted version downloaded from SOAS Research Online: http://eprints.soas.ac.uk/31984

enhance their value-creation capacity and need to develop capabilities tailored to the global environment

The current model also suggests that the underlying HRM system of MNCs is equally important in engendering a sense of commitment in employees. These findings extend a long tradition of research showing that the HRM system exerts a positive impact on commitment (Allen et al., 2003; Gould-Williams, 2003). However, prior research on the HRM system in MNCs has focused primarily on policies and practices specific to international HRM (Black et al., 1992; Brewster, 1991). The current results suggest that HPWPs, which have been studied in domestic firms, can have a positive impact on commitment in MNCs, as they do in domestic firms. Moreover, the finding suggesting a positive relationship between perceived adoption of HPWPs and geocentric orientation lends support to the idea that organizational practices must 'fit' with each other (Baird and Meshoulam, 1988; Snell et al., 1996), an argument often supported by research in domestic firms but rarely studied in MNCs.

The current model further clearly establishes the positive impact of perceived top management team orientations on employee commitment in MNCs. Specifically, the results indicate that the global orientation of top managers and a geocentric orientation are positively related to employee commitment, although modestly so. These findings suggest that the global orientation of top managers in MNCs plays a role in shaping employees' attitudes toward the organization. By exhibiting behaviors that employees see as indicative of an awareness and knowledge of the global competitive environment, top managers enhance employees' commitment to organizational goals. This supports the currently popular view that the success of MNCs is partially dependent on the openness and global outlook of its top managers (Ashkenas et al., 1995; Boyacigiller et al., 2004; Govindarajan and Gupta, 1998; Levy et al., 1999; Murtha et al., 1998; 
This is the version of the article accepted for publication in The International Journal of Human Resource Management published by Taylor and Francis doi:10.1080/09585190801953491

Accepted version downloaded from SOAS Research Online: http://eprints.soas.ac.uk/31984

Rhinesmith, 1992). These findings thus suggest the relevance of investigating the effect of both traditional and MNC-specific antecedents of employee commitment in MNCs. Bolstering this suggestion is the finding in this research that tenure was negatively related to commitment, which is opposite to what has been found in studies in both U.S. and non-U.S. settings (Meyer et al., 2002). Additionally, the relatively weak positive impact of geocentric orientation on commitment bears further investigation to determine the reasons for this finding.

In sum, previous research demonstrating the influence of organizational culture and HPWPs on commitment has not been conducted in MNCs. Similarly, studies on commitment in MNCs have not included organizational culture and HRM policies as antecedents of commitment nor examined the effect of top management orientations specific to MNCs. In the current study, an explicit attempt was made to integrate the literatures on organizational culture, HPWPs and commitment in the context of MNCs. This is the first study, to our knowledge, to explore these relationships.

\section{Implications and Limitations}

This study makes several contributions to the literature. First, the study has several implications for the study of commitment. While various studies of commitment in international contexts have been conducted (Koh et al., 1995; Yousef, 2003), almost none have been conducted in organizations that span multiple countries with the attendant negative forces on commitment formation such as geographic and cultural diversity. Confirming that HRM can, as has been found in some single country settings, have a positive impact on commitment in organizations that span multiple countries is one contribution to the literature. In addition, providing evidence that there are mechanisms unique to MNCs that foster commitment, such as top management team orientations, creates impetus to broaden the types and kinds of organizations in which commitment 
This is the version of the article accepted for publication in The International Journal of Human Resource Management published by Taylor and Francis doi:10.1080/09585190801953491

Accepted version downloaded from SOAS Research Online: http://eprints.soas.ac.uk/31984

is studied. In particular, much remains to be understood about the nature of commitment formation in MNCs, particularly among core employees. For example, does commitment formation in MNCs differ from the processes in purely domestic firms in other ways than those found in this study? What effect, if any, would timing of the firm's internationalization have on these processes (e.g., slow internationalization versus 'born global')?

Second, the study also contributes to the debate over the motivations and impediments to HRM integration in MNCs. The differences in legal, cultural and institutional structures between countries has led many to question whether MNCs should attempt integration, under what circumstances, and what benefits merit the obvious costs (Martin and Beaumont, 1998; Rosenzweig and Nohria, 1994; Taylor et al., 1996). This study provides some support for the viability of instituting a set of common HRM policies across the various units of the $\mathrm{MNC}$, and also for the positive effects it can have on important organizational outcomes such as commitment. It also suggests that HPWPs may have a substantial positive impact on commitment regardless of national origin of the MNC and its employees. Finally, it is important to note that unlike most studies of HPWPs in which the existence of HPWPs were determined from information provided by an HRM representative, we measured employee perception of the existence of HPWPs in the firm, as perception is what most impacts attitude formation.

Third, building a model that combines dimensions of organizational culture and HPWPs with the top management team orientations of global and geocentric orientations is a significant contribution to the study of MNCs and commitment. The model and the results of the study indicate that the international success of firms is dependent to a small but significant degree on top management orientations specific to the MNC (Peng, 2004; Toyne and Nigh, 1997). The global context within which MNCs operate requires a different set of mechanisms (in this case, top 
This is the version of the article accepted for publication in The International Journal of Human Resource Management published by Taylor and Francis doi:10.1080/09585190801953491

Accepted version downloaded from SOAS Research Online: http://eprints.soas.ac.uk/31984

management orientations) that are sui generis to the MNC, to enhance individual performance within the firm. Understanding how these top management team orientations can enhance critical dimensions of organizational culture and HPWPs to impact organizational commitment in MNCs is an important contribution to the study of MNCs. Given their salience in the results, future research should focus on understanding how these particular top management orientations are formed and enacted in MNCs. For example, how do employees come to perceive that top management has a global orientation? How do MNCs acquire or develop managers with such orientations, and at what stage of internationalization do they become critical to international success?

This study has several important limitations. First is the utilization of cross-sectional data to capture a dynamic phenomenon. For example, it is difficult to determine with absolute certainty from the present data whether the creation of global orientation in top managers is a result of organizational culture, or whether top managers with global orientations help build a strong sense of mission and adaptability. Future studies involving longitudinal data could help to settle some of these questions, which have important implications for MNC management as well as management theory.

A second limitation is the utilization of employee commitment as the sole outcome measure. We have argued, for example, that employee commitment is a key component of successful MNC knowledge creation and sharing and the creation of social cohesion among highly diverse employees. Including additional variables such s actual knowledge creation outputs or sharing in the hypothesized model could add weight to the arguments and evidence presented in this study. In addition, linking commitment with actual turnover data would provide greater support for the importance of the primary measure used in this study. The complexity of gathering 
This is the version of the article accepted for publication in The International Journal of Human Resource Management published by Taylor and Francis doi:10.1080/09585190801953491

Accepted version downloaded from SOAS Research Online: http://eprints.soas.ac.uk/31984

the data across multiple countries, types of industries and employees, and seven languages necessitated limiting measurement to key variables.

Finally, this study was bold in its design, including in one research project a wide number of constructs not usually found together, and several constructs (e.g. global orientation) that are relatively new in the literature. Given the large scope of the project and the many practical as well as theoretical implications of the project, we believe that the inclusion of the additional construct was warranted. . In addition, utilization of only survey data may have led to common method variance, which can affect parameter estimates.

In spite of these limitations, the support for the proposed model of commitment formation in MNCs found in this research provides impetus for researchers and global managers alike to give close attention to the ways in which MNCs design their human organizations. When looking for understanding of what helps MNCs to achieve high levels of employee commitment, , this study shows that the HRM system, organizational culture and top management team orientations in place are key factors that must be considered. 
This is the version of the article accepted for publication in The International Journal of Human Resource Management published by Taylor and Francis doi:10.1080/09585190801953491 Accepted version downloaded from SOAS Research Online: http://eprints.soas.ac.uk/31984

\title{
Footnotes
}

\begin{abstract}
${ }^{1}$ While Denison and Mishra's model of organizational culture encompasses four dimensions of culture - mission, adaptability, consistency and involvement - we chose only two of the dimensions for inclusion in this study. There are several reasons for this decision. First, mission and adaptability are the two cultural dimensions most associated with the external orientation of organizational culture, and it is this external environment that is particularly challenging for global firms. Hence firms that are perceived by employees to be effectively dealing with the external environment through nurturing an organizational culture that 'fits' with the environment (Kotter and Heskett, 1992) are more likely to perceive it as successful and hence worthy of commitment. Second, research has found that organizational cultures that are weak on mission and adaptability are unlikely to grow (Denison et al., 2000), and Fey and Denison (2003) found in their study of organizational culture in foreign firms in Russia that adaptability and mission were the strongest predictors of profitability. Employee commitment is likely to be undermined by the attendant sense of stagnation, and nurtured by a sense of corporate financial health.
\end{abstract}

${ }^{2}$ In order to avoid confusion, we use the term "global orientation of top management" to differentiate it from the more popular term 'global mindset'. The definition of global mindset varies across authors (e.g., (Adler \& Bartholomew, 1992; Black, Morrison, \& Gregersen, 1999; Gupta \& Govindarajan, 2000; Kobrin, 1994; Levy, Beechler, Taylor, \& Boyacigiller, 1999; Murtha et al., 1998). However, almost all agree that a key component is an orientation toward, and openness to, the global environment, and therefore we emphasize this aspect.

${ }^{3}$ To be eligible for participation, overseas affiliates had to have a minimum of 100 employees and companies were asked to include both relatively successful and relatively unsuccessful units in the study.

${ }^{4}$ The factorial validity of each scale was assessed by comparing alternative models giving theoretically possible explanations for the covariation among the items. Convergent validity was established using the following criteria: (a) fit indices of the chosen model; (b) significance levels of the item loadings and their standardized values, following the .5 recommended threshold (Kline, 1998); (c) composite reliability index, which is an improved version of the internal consistency coefficient alpha, and should be above .7 (Fornell and Larcker, 1981); (d) variance extracted index, which estimates the amount of variance in the items that is captured by the shared factor and should be above .5 (Fornell and Larcker, 1981).

${ }^{5}$ Because of the well known sensitivity of the chi-square test to sample size and its tendency to detect even trivial differences between the observed and reproduced covariance matrices (Bollen, 1989; Tabachnick and Fidell, 1996) no use has been made of the sequential chi-square tests or the decision-tree framework proposed by Anderson and Gerbing (1988). 
This is the version of the article accepted for publication in The International Journal of Human Resource Management published by Taylor and Francis doi:10.1080/09585190801953491

Accepted version downloaded from SOAS Research Online: http://eprints.soas.ac.uk/31984

\section{References}

Adler, N. J. and Bartholomew, S. (1992) 'Managing Globally Competent People', The Academy of Management Executive, 6: 52-62.

Allen, D., Shore, L. and Griffeth, R. (2003) 'The Role of Perceived Organizational Support and Supportive Human Resource Practices in the Turnover Process', Journal of Management, 29: 99-118.

Allen, N. J. and Meyer, J. P. (1990) 'The Measurement and Antecedents of Affective, Continuance, and Normative Commitment to the Organization', Journal of Occupational Psychology, 63: $1-8$.

Anderson, J. C. and Gerbing, D. W. (1988) 'Structural Equation Modeling in Practice: A Review and Recommended Two-Step Approach', Psychological Bulletin, 103: 411-23.

Aquino, K., Griffeth, R. W., Allen, D. G. and Hom, P. W. (1997) 'Integrating Justice Constructs into the Turnover Process: A Test of a Referent Cognitions Model', Academy of Management Journal, 40: 1208-27.

Arthur, J. (1992) 'The Link Between Business Strategy and Industrial Relations Systems in American Steel Minimills', Industrial and Labor Relations Review, 45: 488-506.

Arthur, J. B. (1994) 'Effects of Human Resource Systems on Manufacturing Performance and Turnover', Academy of Management Journal, 37: 670-87.

Ashkenas, R., Ulrich, D., Jick, T. and Kerr, S. (1995) The Boundaryless Organization: Breaking the Chains of Organizational Structure San Francisco: Jossey-Bass.

Bae, J., Chen, S. J. and Lawler, J. J. (1998) 'Variations in Human Resource Management in Asian Countries: MNC Home-Country and Host-Country Effects', International Journal of Human Resource Management, 9: 653-70.

Baird, L. and Meshoulam, I. (1988) 'Strategic Human Resource Management: Implications for Training Human Resource Professionals', Training and Development Journal, 13: 116-28.

Bartlett, C. A. and Ghoshal, S. (2000) Transnational Management: Text, Cases and Readings in Cross-Border Management (3rd edn). Boston: Irwin/McGraw Hill.

Becker, B. and Gerhart, B. (1996) 'The Impact of Human Resource Management on Organizational Performance: Progress and Prospects', Academy of Management Journal, 39: 779-80.

Becker, B. E. and Huselid, M. A. (1998) 'High Performance Work Systems and Firm Performance: A Synthesis of Research and Managerial Implications'. In Ferris, G. (ed) Research in Personnel and Human Resource Management. Greenwich, CT: JAI Press, pp. 53-101.

Bentler, P. M. (1995) EQS Structural Equations Program Manual Encino, CA: Multivariate Software.

Birnbaum, P. H. and Wong, G. Y. Y. (1985) 'Organizational Structure of Multinational Banks in Hong Kong from a Culture-Free Perspective', Administrative Science Quarterly, 30: 26277.

Black, J. S., Gregersen, H. B. and Mendenhall, M. E. (1992) Global Assignments San Francisco: Jossey-Bass.

Black, J. S., Morrison, A. J. and Gregersen, H. B. (1999) Global Explorers: The Next Generation of Leaders New York: Routledge.

Blau, P. (1964) Exchange and Power in Social Life New York: Wiley.

Bollen, K. A. (1989) Structural Equations with Latent Variables New York: Wiley.

Boomsma, A. (2000) 'Reporting Analyses of Covariance Structures', Structural Equation Modeling, 7: 461-83. 
This is the version of the article accepted for publication in The International Journal of Human Resource Management published by Taylor and Francis doi:10.1080/09585190801953491

Accepted version downloaded from SOAS Research Online: http://eprints.soas.ac.uk/31984

Boyacigiller, N., Beechler, S., Taylor, S. and Levy, O. (2004) 'The Crucial Yet Elusive Global Mindset'. In Lane, H. W., Maznevski, M. L., Mendenhall, M. and McNett, J. (eds) The Handbook of Global Organizing and Managing. Blackwell Publishers, pp.

Brewer, A. (1994) The Responsive Employee Sydney: Allen and Unwin.

Brewster, C. J. (1991) The Management of Expatriates London: Kogan Page.

Buckley, P. J. and Casson, M. C. (1998) 'Models of the Multinational Enterprise', Journal of International Business Studies, 29: 21-44.

Butler, J. E., Ferris, G. R. and Napier, N. K. (1991) Strategy and Human Resources Management Cincinnati: South-Western Publishing Co.

Byrne, B. M. (1994) Structural Equation Modeling with EQS and EQS/WINDOWS: Basic Concepts, Application, and Programming California: Sage.

Cappelli, P. and Singh, H. (1992) 'Integrating Strategic Human Resources and Strategic Management'. In Lewin, D., Mitchell, O. S. and Sherer, P. D. (eds) Research Frontiers in Industrial Relations and Human Resources. Madison, WI: Industrial Relations Research Association, pp. 165-92.

Carlson, M. and Mulaik, S. A. (1993) 'Trait Ratings from Descriptive of Behavior as Mediated by Components of Meaning', Multivariate Behavioral Research, 28: 111-59.

Cohen, P., Cohen, J., Teresi, J., Marchi, M. and Velez, N. C. (1990) 'Problems in the Measurement of Latent Variables in Structural Equations Casual Models', Applied Psychological Measurement: 183-96.

Collins, J. C. and Porras, J. I. (1997) Built to Last: Successful Habits of Visionary Companies (1 ${ }^{\text {st }}$ Paperback). New York: Harper-Business.

Daft, R. L. (1992) Organization Theory and Design (4th edn). St. Paul, MN: West Publishing Company.

Daft, R. L. and Weick, K. E. (1984) 'Toward a Model of Organizations as Interpretation Systems', Academy of Management Review, 9: 284-95.

Delaney, J. T. and Huselid, M. A. (1996) 'The Impact of Human Resource Management Practices on Perceptions of Organizational Performance', Academy of Management Journal, 39: 94969.

Delery, J. and Doty, D. H. (1996) 'Modes of Theorizing in Strategic Human Resource Management: Tests of Universalistic, Contingency, and Configurational Performance Predictions', Academy of Management Journal, 39: 802-35.

Denison, D. R., Cho, H. J. and Young, J. (2000) 'Diagnosing Organizational Cultures: Validating a Model and Method', Working Paper at International Institute for Management Development, Lausanne, Switzerland.

Denison, D. R. and Mishra, A. K. (1995) 'Toward a Theory of Organizational Culture and Effectiveness', Organization Science, 6: 204-23.

Denison, D. R. and Neale, W. S. (1996) Denison Organizational Culture Survey Ann Arbor, MI: Aviat.

Dessler, G. (1999) 'How to Earn Your Employees' Commitment', The Academy of Management Executive, 13: 58-67.

Doz, Y. L. and Prahalad, C. K. (1991) 'Managing DMNCs: A Search for a New Paradigm', Strategic Management Journal, 12: 145-64.

Estienne, M. (1997) 'The Art of Cross-Cultural Management: "An Alternative Approach to Training and Development"', Journal of European Industrial Training, 21: 14-18. 
This is the version of the article accepted for publication in The International Journal of Human Resource Management published by Taylor and Francis doi:10.1080/09585190801953491

Accepted version downloaded from SOAS Research Online: http://eprints.soas.ac.uk/31984

Evans, P. and Doz, Y. L. (1992) 'Dualities: A Paradigm for Human Resource and Organizational Development in Complex Multinationals'. In Pucik, V., Tichy, N. and Barnett, C. (eds) Globalizing Management: Creating and Leading the Competitive Organization. New York: John Wiley \& Sons, pp.

Fey, C. F. and Denison, D. R. (2003) 'Organizational Culture and Effectiveness: Can American Theory Be Applied in Russia?' Organization Science, 14: 686-706.

Fornell, C. and Larcker, D. F. (1981) 'Evaluating Structural Equation Models with Observable Variables and Measurement Error', Journal of Marketing Research, 18: 39-50.

Gouldner, A. W. (1960) 'The Norm of Reciprocity: A Preliminary Statement', American Sociological Review, 25: 161-78.

Gould-Williams, J. (2003) 'The Importance of HR Practices and Workplace Trust in Achieving Superior Workplace Performance : A Study of Public-Sector Organizations', International Journal of HRM, 14: 28-54.

Gould-Williams, J. S. (1998) 'The Impact of HRM Practices on Organisational Commitment'. In Neely, A. D. and Waggoner, D. B. (eds) Performance Measurement: Theory and Practice. Cambridge: Centre for Business Performance, Cambridge University, pp. 404-11.

Govindarajan, V. and Gupta, A. (1998) 'Success is All in the Mindset', Financial Times, February 27.

Guest, D. and Conway, N. (1997) Employee Motivation and the Psychological Contract London: CIPD.

Gupta, A. K. and Govindarajan, V. (2000) 'Managing Global Expansion: A Conceptual Framework', Business Horizons, 43: 45-54.

Hair, J. F., Anderson, R. E., Tatham, R. L. and Black, W. C. (1995) Multivariate Data Analysis with Readings (4th edn). New Jersey: Prentice Hall.

Harley, B. (2002) 'Employee Responses to High Performance Work System Practices: An Analysis of the AWIRS95 Data', Journal of Industrial Relations, 44: 418-34.

Harrison, J. K. and Hubbard, R. (1998) 'Antecedents to Organizational Commitment Among Mexican Employees of a U.S. Firm in Mexico', The Journal of Social Psychology, 138: 609-23.

Harvey, M., Speier, C. and Novicevic, M. M. (1999) 'The Role of Inpatriation in Global Staffing', International Journal of Human Resource Management, 10: 459-76.

Hedlund, G. (1986) 'The Hypermodern MNC -- A Heterarchy?' Human Resource Management, 25 : 9-35.

Hope, V. (1994) 'HRM and Corporate Cultural Control: The limits to Commitment', Paper presented to the 1994 Annual Conference of the British Academy of Management, Lancaster University.

Howell, J. P. and Dorfman, P. W. (1986) 'Leadership and Substitutes for Leadership Among Professional and Non-Professional Workers', Journal of Applied Behavioral Science, 22: $29-46$.

Hu, L. and Bentler, P. M. (1998) 'Fit Indices in Covariance Structure Modeling: Sensitivity to Under-Parameterized Model Misspecification', Psychological Methods, 3: 424-53.

Huselid, M. (1995) 'The Impact of Human Resource Management Practices on Turnover, Productivity, and Corporate Financial Performance', Academy of Management Journal, 38: 635-72.

Iles, P., Mabey, C. and Roberston, I. (1990) 'HRM Practices and Employee Commitment: Possibilities, Pitfalls and Paradoxes.' British Journal of Management, 1: 147-57. 
This is the version of the article accepted for publication in The International Journal of Human Resource Management published by Taylor and Francis doi:10.1080/09585190801953491

Accepted version downloaded from SOAS Research Online: http://eprints.soas.ac.uk/31984

Kabanoff, B. (1997) 'Organizational Justice Across Cultures: Integrating Organizational-Level and Culture-Level Perspectives'. In Earley, P. C. and Erez, M. (eds) New Perspectives on International Industrial/Organizational Psychology. San Francisco: New Lexington Press, pp. 676-712.

Kanter, R. M. (1972) Commitment and Community: Communes and Utopias in Sociological Perspective Cambridge, Mass.: Harvard University Press.

Kanter, R. M. (1994) 'Afterword: What 'Thinking Globally' Really Means'. In Barnwik, R. S. and Kanter, R. M. (eds) Global Strategies. Boston: Harvard Business School Press, pp. 227-32.

Kline, R. B. (1998) Principles and Practice of Structural Equation Modeling New York: The Guilford Press.

Kobrin, S. J. (1994) 'Is There a Relationship between a Geocentric Mind-Set and Multinational Strategy?' Journal of International Business Studies, 25: 493-511.

Kogut, B. and Zander, U. (1996) 'What Firms Do? Coordination, Identity, and Learning.' Organization Science, 7: 502-18.

Koh, W. L., Steers, R. M. and Terbog, J. R. (1995) 'The Effects of Transformational Leadership on Teacher Attitudes and Student Performance in Singapore', Journal of Organizational Behavior, 16: 319-33.

Kotter, J. P. and Heskett, J. L. (1992) Corporate Culture and Performance New York: The Free Press.

Kouzes, J. M. and Posner, B. Z. (2002) The Leadership Challenge (3rd edn). San Francisco, CA: Jossey-Bass.

Laurent, A. (1983) 'The Cultural Diversity of Western Conceptions of Management', International Studies of Management and Organizations, 13: 75-96.

Lepak, D. P. and Snell, S. A. (2002) 'Examining the Human Resource Architecture: The Relationship among Human Capital, Employment, and Human Resource Configurations', Journal of Management, 28: 517-43.

Levy, O., Beechler, S., Taylor, S. and Boyacigiller, N. (1999) 'What We Talk about When We Talk about Global Mindset?‘, The International Management Division, Academy of Management Meetings, Chicago, IL.

Lok, P. and Crawford, J. (2001) 'Antecedents of Organizational Commitment and the Mediating Role of Job Satisfaction', Journal of Managerial Psychology, 16: 594-613.

Luthans, F., McCaul, H. and Dodd, N. (1985) 'Organizational Commitment: A Comparison of American, Japanese, and Korean Employees', Academy of Management Journal, 28: 21319.

MacDuffie, J. P. (1995) 'Human Resource Bundles and Manufacturing Performance Organizational Logic and Flexible Production Systems in the World Auto Industry', Industrial and Labor Relations Review, 48: 197-221.

MacDuffie, J. P. and Kochan, T. A. (1995) 'Do U.S. Firms Invest Less in Human Resources? Training in the World Auto Industry', Industrial Relations, 34: 147-68.

Martin, G. and Beaumont, P. (1998) 'Diffusing 'Best Practice' in Multinational Firms: Prospects, Practice and Contestation', International Journal of Human Resource Management, 9: 67196.

Mathieu, J. E. and Zajac, D. (1990) 'A Review and Meta-Analysis of the Antecedents, Correlates, and Consequences of Organizational Commitment', Psychological Bulletin, 108: 171-94.

Maznevski, M. L. and Lane, H. W. (2004) 'Shaping the Global Mindset: Designing Educational Experiences for Effective Global Thinking and Action'. In Boyacigiller, N., Goodman, R. 
This is the version of the article accepted for publication in The International Journal of Human Resource Management published by Taylor and Francis doi:10.1080/09585190801953491

Accepted version downloaded from SOAS Research Online: http://eprints.soas.ac.uk/31984

M. and Phillips, M. (eds) Crossing Cultures: Insights from Master Teachers. London: Routledge, pp. 171-84.

McCaul, H., Hinsz, V. and McCaul, K. (1995) 'Assessing Organizational Commitment: An Employee's Global Attitude towards the Organization', Journal of Applied Behavioural Science, 31: 80-90.

Medsker, G. J., Williams, L. J. and Holahan, P. J. (1994) 'A Review of Current Practices for Evaluating Casual Models in Organizational Behavior and Human Resources Management Research', Journal of Management, 20: 439-64.

Meyer, J. P. and Allen, N. J. (1991) 'A Three-Component Conceptualization of Organizational Commitment', Human Resource Management Review, 1: 61-89.

Meyer, J. P., Stanley, D. J., Herscovitch, L. and Topolnytsky, L. (2002) 'Affective, Continuance, and Normative Commitment to the Organization: A Meta-Analysis of Antecedents, Correlates, and Consequences', Journal of Vocational Behavior, 61: 20-52.

Mowday, R. T., Porter, L. W. and Steers, R. M. (1982) Employee-Organization Linkages: The Psychology of Commitment, Absenteeism and Turnover New York: Academic Press.

Mowday, R. T., Steers, R. M. and Porter, L. W. (1979) 'The Assessment of Organizational Commitment', Journal of Vocational Behavior, 14: 224-47.

Mueller, C., Wallace, J. and Price, J. (1992) 'Employee Commitment: Resolving Some Issues', Work and Occupation, 19: 211-36.

Mulaik, S. A., James, L. R., Van Alstine, J., Bennett, N., Lind, S. and Stilwell, C. D. (1989) 'An Evaluation of Goodness-of-Fit Indices for Structural Equation Models.' Psychological Bulletin, 105: 430-45.

Murtha, T. P., Lenway, S. A. and Bagozzi, R. P. (1998) 'Global Mind-Sets and Cognitive Shift in a Complex Multinational Corporation', Strategic Management Journal, 19: 97-114.

Nadler, D. and Tushman, M. L. (1980) 'A Congruence Model for Diagnosing Organizational Behavior'. In Miles, R. (ed) Resource Book in Macro Organizational Behavior. Santa Clara, CA: Goodyear, pp. 30-49.

Nahapiet, J. and Ghoshal, S. (1998) 'Social Capital, Intellectual Capital, and the Organizational Advantage', Academy of Management Review, 23: 242-66.

Nohria, N. and Ghoshal, S. (1994) 'Differentiated Fit and Shared Values: Alternatives for Managing Headquarters-Subsidiary Relations', SMJ, 15: 491-502.

Nohria, N. and Ghoshal, S. (1997) The Differentiated Network: Organizing Multinational Corporations for Value Creation San Francisco: Jossey-Bass Publishers.

O'Reilly, C. and Chatman, J. A. (1996) 'Culture as Social Control: Corporations, Cults, and Commitment'. In Staw, B. M. and Cummings, L. L. (eds) Research in Organizational Behavior. pp. 157-200.

Peng, M. W. (2004) 'Identifying the Big Question in International Business Research', Journal of International Business Studies, 35: 99-108.

Perlmutter, H. (1969) 'The Tortuous Evolution of the Multinational Corporation', Columbia Journal of World Business, January-February: 9-18.

Peterson, D. K., Puia, G. M. and Suess, F. R. (2003) '"Yo Tengo La Camiseta (I Have the Shirt On)": An Exploration Of Job Satisfaction and Commitment Among Workers in Mexico', Journal of Leadership \& Organizational Studies, 10: 73-88.

Pfeffer, J. (1996) 'When it Comes to 'Best Practices'--Why Do Smart Organizations Occasionally Do Dumb Things?' Organizational Dynamics, 25: 33-44.

Pfeffer, J. (1998) The Human Equation Boston: Harvard Business School Press. 
This is the version of the article accepted for publication in The International Journal of Human Resource Management published by Taylor and Francis doi:10.1080/09585190801953491

Accepted version downloaded from SOAS Research Online: http://eprints.soas.ac.uk/31984

Ramsay, H., Scholarios, D. and Harley, B. (2000) 'Employee and High-Performance Work Systems: Testing Inside the Black Box', British Journal of Industrial Relations, 38: 501-32. Raykov, T., Tomer, A. and Nesselroade, J. R. (1991) 'Reporting Structural Equation Modeling Results in Psychology and Aging: Some Proposed Guidelines', Psychology and Aging, 6: 499-503.

Reade, C. (2001) 'Dual Identification in Multinational Corporations: Local Managers, and their Psychological Attachment to the Subsidiary versus the Global Organization.' International Journal of HRM, 12: 405-24.

Rhinesmith, S. H. (1992) 'Global Mindsets for Global Managers', Training \& Development, 46: 6369.

Rhinesmith, S. H. (1993) Globalization: Six Keys to Success in a Changing World Alexandria, VA: The American Society For Training and Development.

Rhinesmith, S. H. (1996) A Manager's Guide to Globalization: Six Skills for Success in a Changing World (2nd edn). New York: McGraw-Hill.

Ronen, S. and Shenkar, O. (1985) 'Clustering Countries on Attitudinal Dimensions: A Review and Synthesis', Academy of Management Review, 10: 435-54.

Rosenzweig, P. M. and Nohria, N. (1994) 'Influences on Human Resource Management Practices in Multinational Corporations', Journal of International Business Studies, 25: 229-51.

Schein, E. H. (1985) Organizational Culture and Leadership San Francisco: Jossey-Bass.

Schumacker, R. E. and Lomax, R. G. (1996) A Beginner's Guide to Structural Equation Modeling New Jersey: Lowrence Erlbaum Associates Publishers.

Shook, C. L., Ketchen, D. J., Hult, G. T. M. and Kacmar, K. M. (2004) 'An Assessment of the Use of Structural Equation Modeling in Strategic Management Research', Strategic Management Journal, 25: 397-404.

Sigler, T. and Pearson, C. (2000) 'Creating and Empowering Culture: Examining the Relationship between Organizational Culture and Perceptions of Empowerment', Journal of Quality Management, 5: 27-52.

Snell, S., Youndt, M. and Wright, P. (1996) 'Establishing a Framework for Research in Strategic Human Resource Management: Merging Resource Theory and Organizational Learning', Research in Personnel and Human Resource Management, 14: 61-90.

Storey, J. and Quintas, P. (2001) 'Knowledge Management and Human Resources Management'. In Storey, J. (ed) Human Resource Management: A Critical Text. London: Thomson Learning, pp. 339-63.

Swailes, S. (2002) 'Organizational Commitment: A Critique of the Construct and Measures', International Journal of Management Reviews, 4: 155-78.

Tabachnick, B. G. and Fidell, L. S. (1996) Using Multivariate Statistics California: Harper Collins Publishers.

Taylor, S., Beechler, S. and Napier, N. (1996) 'Toward an Integrative Model of Strategic International Human Resource Management', The Academy of Management Review, 21: 959-85.

Toyne, B. and Nigh, D. (1997) International Business: An Emerging Vision Columbia, South Carolina: South Carolina University Press.

Tsui, A. S., Egan, T. D. and Xin, K. R. (1995) 'Diversity in Organizations: Lessons from Demography Research'. In Chemers, M., Costanzo, M. and Oskamp, S. (eds) Diversity in Organization. Newbury Park, CA: Sage Publications, pp. 
This is the version of the article accepted for publication in The International Journal of Human Resource Management published by Taylor and Francis doi:10.1080/09585190801953491

Accepted version downloaded from SOAS Research Online: http://eprints.soas.ac.uk/31984

Tsui, A. S., Pearce, J. L., Porter, L. W. and Tripoli, A. M. (1997) 'Alternative Approaches to the Employee-Organization Relationship: Does Investment in Employees Pay Off?' Academy of Management Journal, 40: 1089-121.

Virtanen, T. (2000) 'Commitment and the Study of Organizational Climate and Culture'. In Ashkanasy, N. M., Wilderom, C. P. M. and Peterson, M. F. (eds) Handbook of Organizational Culture and Climate. Thousand Oaks, CA: Sage, pp. 339-54.

Wayne, S. J., Shore, L. M., Bommer, W. H. and Tetrick, L. E. (2002) 'The Role of Fair Treatment and Rewards in Perceptions of Organizational Support and Leader-Member Exchange', Journal of Applied Psychology, 87: 590-8.

Wayne, S. J., Shore, L. M. and Liden, R. C. (1997) 'Perceived Organizational Support and LeaderMember Exchange: A Social Exchange Perspective', Academy of Management Journal, 40: 82-111.

Whitener, E. M. (2001) 'Do High Commitment Human Resource Practices Affect Employee Commitment?' Journal of Management, 27: 515-35.

Wilkins, A. L. and Ouchi, W. G. (1983) 'Efficient Cultures: Exploring the Relationship between Culture and Organizational Performance', Administrative Science Quarterly, 28: 468-81.

Wright, P., Gardner, T., Moynihan, L. and Allen, M. (2005) 'The relationship between HR Practices and Firm Performance: Examining Causal Order', Personnel Psychology, 58: 40946.

Wright, P. M. and McMahan, G. C. (1992) 'Theoretical Perspectives for Strategic Human Resource Management', Journal of Management, 18: 295-320.

Youndt, M. A., Snell, S. A., Dean, J. W. J. and Lepak, D. P. (1996) 'Human Resource Management, Manufacturing Strategy, and Firm Performance', Academy of Management Journal, 39: 836-66.

Yousef, D. A. (2000) 'Organizational Commitment: A Mediator of the Relationships of Leadership Behavior with Job Satisfaction and Performance in a Non-Western Country', Journal of Managerial Psychology, 15: 6-24.

Yousef, D. A. (2003) 'Validating the Dimensionality of Porter et al.'s Measurement of Organizational Commitment in a Non-Western Culture Setting', International Journal of Human Resource Management, 14: 1067-79. 
This is the version of the article accepted for publication in The International Journal of Human Resource Management published by Taylor and

Francis doi:10.1080/09585190801953491

Accepted version downloaded from SOAS Research Online: http://eprints.soas.ac.uk/31984

Table 1

Means, Standard Deviations, Reliability Estimates and Correlations Using Composite Scores ${ }^{1}$

\begin{tabular}{|c|c|c|c|c|c|c|c|c|c|c|c|c|c|}
\hline & Variable & $\mathbf{M}$ & S.D. & 1 & 2 & 3 & 4 & 5 & 6 & 7 & 8 & 9 & 10 \\
\hline 1. & HPWPs & 4.43 & 1.14 & .80 & & & & & & & & & \\
\hline 2. & Mission & 3.31 & .78 & $.66^{*}$ & .91 & & & & & & & & \\
\hline 3. & Adaptability & 3.18 & .65 & $.62 *$ & $.70^{*}$ & .73 & & & & & & & \\
\hline 4. & Global orientation & 5.10 & 1.25 & $.50^{*}$ & $.63^{*}$ & $.51^{*}$ & .81 & & & & & & \\
\hline 5. & Geocentric orientation & 4.38 & 1.25 & $.33^{*}$ & $.35^{*}$ & $.34 *$ & $.30^{*}$ & .72 & & & & & \\
\hline 6. & Commitment & 4.98 & 1.16 & $.63^{*}$ & $.61^{*}$ & $.59^{*}$ & $.49^{*}$ & $.33^{*}$ & .91 & & & & \\
\hline 7. & Tenure & 9.07 & 7.78 & .01 & .04 & $-.05^{*}$ & .05 & $.06^{*}$ & -.02 & ----- & & & \\
\hline 8. & Gender & .69 & .46 & .02 & -.03 & $-.05^{*}$ & $-.08^{*}$ & $-.08 *$ & .01 & $.21 *$ & ---- & & \\
\hline 9. & $\begin{array}{l}\text { Home-host nationality of } \\
\text { employees }\end{array}$ & .38 & .49 & -.01 & $.07 *$ & -.02 & $.06^{*}$ & $.11^{*}$ & -.03 & $.13^{*}$ & .03 & ---- & \\
\hline 10. & Cosmopolitan background & .99 & 1.02 & $.10^{*}$ & $.11^{*}$ & $.09 *$ & $.05^{*}$ & -.01 & $.06^{*}$ & $-.05^{*}$ & .03 & $-.07 *$ & --- \\
\hline 11. & Parent country nationality & .64 & .48 & $.23^{*}$ & $.24 *$ & $.15^{*}$ & $.19^{*}$ & $.29^{*}$ & $.18^{*}$ & $.16^{*}$ & 0 & -.02 & .05 \\
\hline
\end{tabular}

${ }^{1} \mathrm{~N}=1664$. Numbers on the diagonal are internal consistency reliability estimates (coefficient alpha).

$* \mathrm{p}<.05$. 
This is the version of the article accepted for publication in The International Journal of Human Resource Management published by Taylor and

Francis doi:10.1080/09585190801953491

Accepted version downloaded from SOAS Research Online: http://eprints.soas.ac.uk/31984

\section{Table 2}

Reliabilities Estimates, Variance Extracted, and Correlations Using Factors Scores ${ }^{2}$

\begin{tabular}{|c|c|c|c|c|c|c|c|c|c|c|c|c|c|}
\hline & Variable & 1 & 2 & 3 & 4 & 5 & 6 & 7 & 8 & 9 & 10 & 11 & $\begin{array}{l}\text { Variance } \\
\text { extracted }\end{array}$ \\
\hline 1. & HPWP & .91 & & & & & & & & & & & .77 \\
\hline 2. & Mission & $.76^{*}$ & .92 & & & & & & & & & & .55 \\
\hline 3. & Adaptability & $.82 *$ & $.84 *$ & .86 & & & & & & & & & .68 \\
\hline 4. & Global orientation & $.62 *$ & $.73^{*}$ & $.66^{*}$ & .81 & & & & & & & & .59 \\
\hline 5. & Geocentric orientation & $.44 *$ & $.42 *$ & $.46^{*}$ & $.40 *$ & .72 & & & & & & & .40 \\
\hline 6. & Commitment & $.74 *$ & $.66^{*}$ & $.73^{*}$ & $.56^{*}$ & $.42 *$ & .91 & & & & & & .55 \\
\hline 7. & Tenure & .01 & .05 & -.05 & .05 & .06 & -.04 & $.90^{\mathrm{a}}$ & & & & & ---- \\
\hline 8. & Gender & .01 & -.04 & $-.07 *$ & $-.10^{*}$ & $-.10^{*}$ & .02 & $.23 *$ & $.90^{\mathrm{a}}$ & & & & ----- \\
\hline 9 & Home country-Host country & -.02 & $.07 *$ & -.02 & $.07 *$ & $.14^{*}$ & -.03 & $.14 *$ & .04 & $.90^{\mathrm{a}}$ & & & ---- \\
\hline 10. & Cosmopolitan background & $.11^{*}$ & $.12 *$ & $.12 *$ & $.06^{*}$ & -.03 & $.08 *$ & $-.06^{*}$ & .03 & $-.08 *$ & $.90^{\mathrm{a}}$ & & ---- \\
\hline 11. & Parent country nationality & $.28 *$ & $.26^{*}$ & $.20 *$ & $.21 *$ & $.33 *$ & $.22 *$ & $.18 *$ & 0 & -.02 & $.05^{*}$ & $.90^{\mathrm{a}}$ & ----- \\
\hline
\end{tabular}

\footnotetext{
$\overline{2}$ Based on results from the measurement sub-model. Numbers on the diagonal are composite reliability estimates. Fixed reliability for a single-item construct.

$\mathrm{N}=1664 ; * \mathrm{p}<.05$
} 
This is the version of the article accepted for publication in The International Journal of Human Resource Management published by Taylor and Francis doi:10.1080/09585190801953491

Accepted version downloaded from SOAS Research Online: http://eprints.soas.ac.uk/31984

\section{Table 3}

\section{Fit Indices for Compared Models ${ }^{3}$}

\begin{tabular}{|c|c|c|c|c|c|c|c|}
\hline Model & $\mathrm{s}-\mathrm{b} \chi^{2}$ & df & SRMSR & CFI & $\mathrm{NFI}^{\mathrm{a}}$ & $\mathrm{PCFI}^{\mathrm{b}}$ & $\mathrm{PNFI}^{\mathrm{b}}$ \\
\hline \multicolumn{8}{|l|}{ Hypothesized $^{4}$} \\
\hline & $3737.88^{*}$ & 1074 & .042 & .918 & .888 & .839 & .812 \\
\hline Null $^{5}$ & $7234.89 *$ & 1086 & .201 & .810 & .784 & .748 & .724 \\
\hline Alternative $1^{6}$ & $4075.51 *$ & 1077 & .056 & .907 & .878 & .831 & .804 \\
\hline Alternative $2^{7}$ & $3743.49 *$ & 1075 & .042 & .917 & .888 & .839 & .812 \\
\hline Alternative $3^{8}$ & $4410.74 *$ & 1076 & .097 & .897 & .868 & .821 & .795 \\
\hline${\text { Alternative } 4^{9}}^{9}$ & $4586.90 *$ & 1078 & .104 & .891 & .863 & .817 & .791 \\
\hline Alternative $5^{10}$ & $3753.36^{*}$ & 1076 & .043 & .917 & .888 & .839 & .812 \\
\hline Measurement $^{11}$ & $3724.31 *$ & 1071 & .042 & .918 & .889 & .836 & .810 \\
\hline
\end{tabular}

a. Robust index, using Sattora-Bentler scaled $\chi^{2}$. the calculation of NFI were based on the tested and independent model chi-squares.

b. Parsimonious index using the parsimony ratio with degrees of freedom from the independent model (Mulaik et al., 1989).

$\mathrm{N}=1664 ; * \mathrm{p}<.001$

\footnotetext{
${ }^{3}$ The chi-square of the independence model (all the parameters relating between the items are fixed to zero): $\chi^{2}(1176)=33510.98, \mathrm{p}<.001$.

${ }^{4}$ Hypothesized model: The organizational culture and HRM constructs effects commitment directly and indirectly.

${ }^{5}$ Control model only: the control variables relate to the latent variables and to each other. All parameters relating to the latent constructs are fixed to zero.

${ }^{6}$ Constrained model: The organizational culture and HRM constructs affect commitment only indirectly through the TMT orientation constructs.

${ }^{7}$ Constrained model: The organizational culture and HRM constructs affect commitment indirectly; global orientation affects commitment indirectly through geocentric orientation. .

${ }^{8}$ Constrained model: The organizational culture constructs affect commitment only directly; the HRM construct affects commitment both directly and indirectly through geocentric orientation; the TMT orientation constructs affect commitment directly.

${ }^{9}$ Constrained model: The organizational culture and HRM constructs affect commitment only directly; the TMT orientation constructs affect commitment directly.

${ }^{10}$ Constrained model: The organizational culture and HRM constructs affect commitment directly; the TMT orientation constructs do not affect commitment.

${ }^{11}$ Measurement model: All the constructs related to each other.
} 
This is the version of the article accepted for publication in The International Journal of Human Resource Management published by Taylor and Francis doi:10.1080/09585190801953491

Accepted version downloaded from SOAS Research Online: http://eprints.soas.ac.uk/31984

Figure 1

Hypothesized Model

Fundamentals of the Human Organization
Top Management Team

Orientations

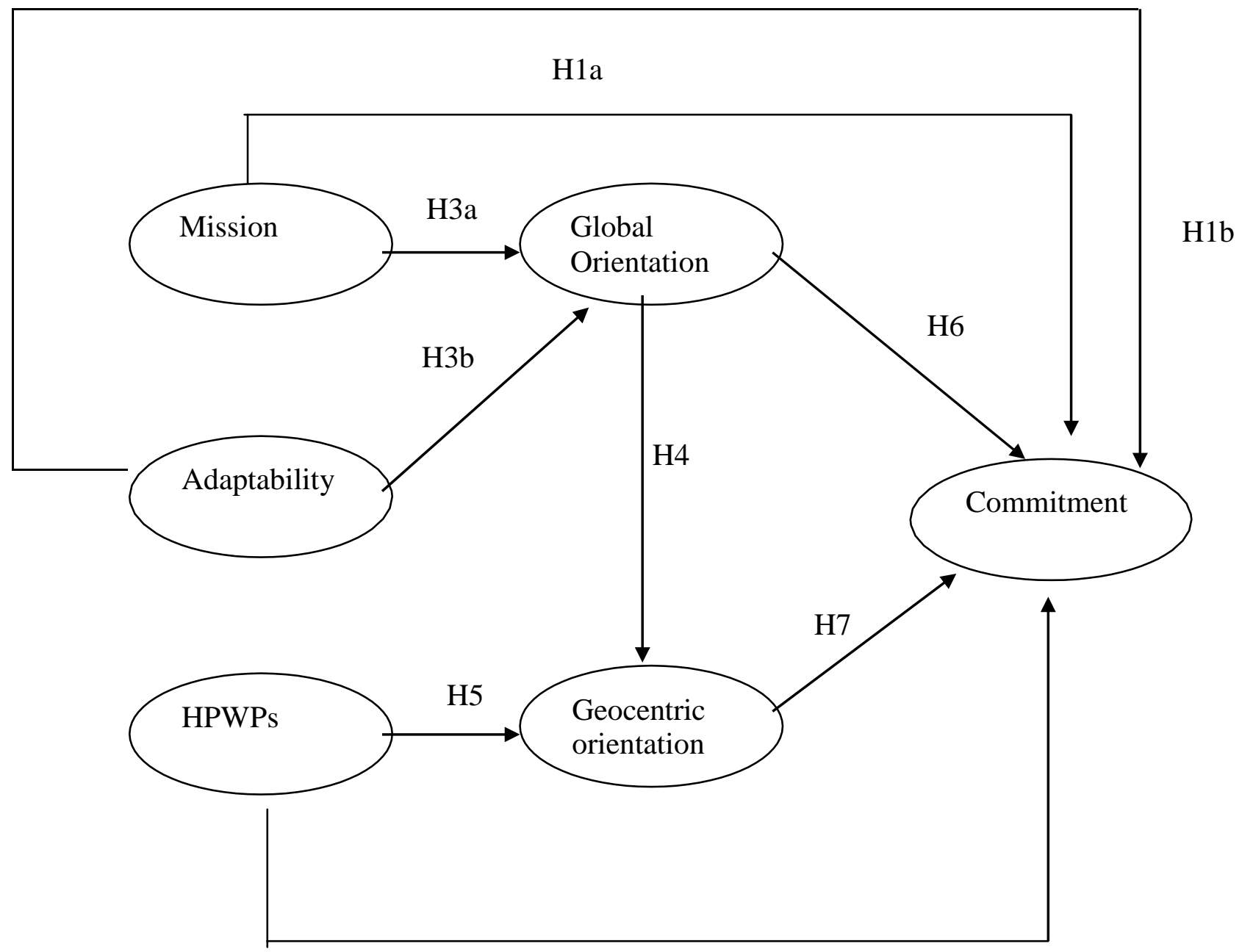

$\mathrm{H} 2$ 
This is the version of the article accepted for publication in The International Journal of Human Resource Management published by Taylor and Francis doi:10.1080/09585190801953491

Accepted version downloaded from SOAS Research Online: http://eprints.soas.ac.uk/31984

Figure 2

Results of the Structural Equation Model $^{12}$

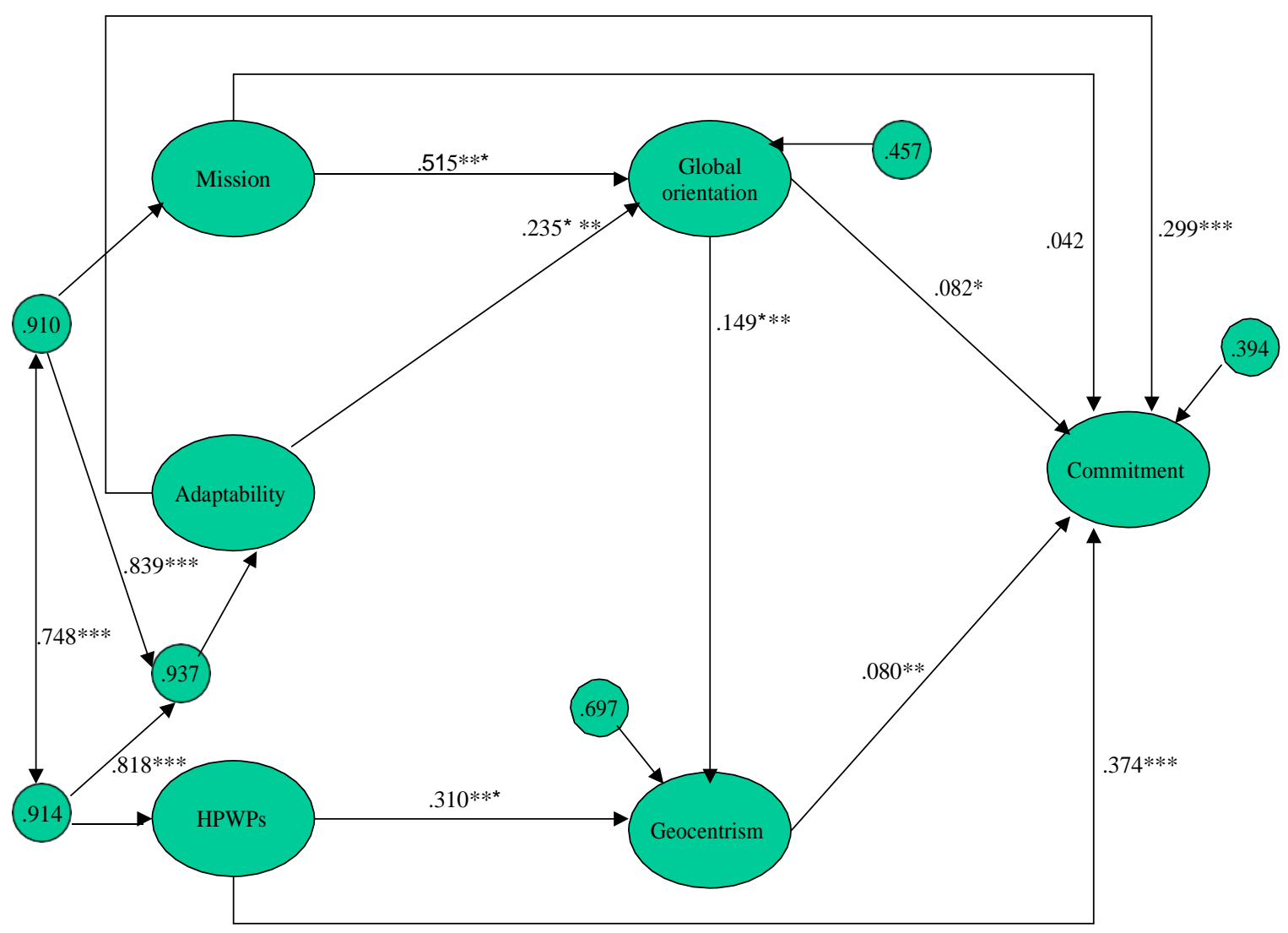

${ }^{12}$ Standardized path coefficients for the hypothesized model. Numbers inside the small circles are standardized residual variances. Control variables' effects are not shown.

$\mathrm{N}=1664 ; * \mathrm{p}<.05 * * \mathrm{p}<.01 * * * \mathrm{p}<.001$ one-sided 
This is the version of the article accepted for publication in The International Journal of Human Resource Management published by Taylor and Francis doi:10.1080/09585190801953491

Accepted version downloaded from SOAS Research Online: http://eprints.soas.ac.uk/31984

\section{APPENDIX}

High Performance Work Practice Measures (source of each item in parenthesis)

1. This organization treats employees as permanent (Delery and Doty, 1996)

2. This organization hires new employees with care (Huselid, 1995)

3. This organization tries to retain rather than release employees when their jobs are eliminated (Delery and Doty, 1996).

4. Whenever possible, this organization promotes employees from within the company rather than filling positions with outside candidates (Huselid, 1995)

5. This organization closely links employee rewards to individual performance (Huselid, 1995; MacDuffie, 1995)

6. In this organization, performance appraisals are based on objective, quantifiable results (Delery and Doty, 1996)

7. This organization ties employee rewards to group/team performance (Pfeffer, 1998).

8. In this organization, there is support for growth and development of employees (Delery and Doty, 1996)

9. In this organization, a high level of training is provided throughout employees' careers (Arthur, 1992; Huselid, 1995; MacDuffie, 1995; Pfeffer, 1998)

10. This organization cross-trains employees (MacDuffie, 1995) 
This is the version of the article accepted for publication in The International Journal of Human Resource Management published by Taylor and Francis doi:10.1080/09585190801953491

Accepted version downloaded from SOAS Research Online: http://eprints.soas.ac.uk/31984

\section{Results of the Measurement Sub-Model Evaluation}

\section{Table 4}

Fit Indices for Models Compared in Each Scale ${ }^{13}$

\begin{tabular}{|c|c|c|c|c|c|c|c|}
\hline Models compared & $s-b \chi^{2}$ & df & SRMSR & CFI $^{a}$ & NFI $^{a}$ & PCFI $^{b}$ & PNFI $^{b}$ \\
\hline \multicolumn{8}{|l|}{ HPWP } \\
\hline One factor & $559.27 * *$ & 35 & .054 & .893 & .887 & .695 & .690 \\
\hline Second-order & $201.45 * *$ & 32 & .034 & .965 & .959 & .686 & .682 \\
\hline \multicolumn{8}{|l|}{ Mission } \\
\hline One factor & $186.65 * *$ & 27 & .026 & .974 & .970 & .731 & .728 \\
\hline Second-order & $115.77 * *$ & 24 & .020 & .985 & .981 & .657 & .654 \\
\hline \multicolumn{8}{|l|}{ Adaptability } \\
\hline One factor & $735.25 * *$ & 27 & .080 & .809 & .804 & .607 & .603 \\
\hline Second-order & $152.51 * *$ & 24 & .044 & .965 & .959 & .643 & .639 \\
\hline \multicolumn{8}{|l|}{ Geocentrism } \\
\hline One factor & $10.70 *$ & 2 & .018 & .991 & .989 & .330 & .330 \\
\hline \multicolumn{8}{|l|}{ Commitment } \\
\hline One factor & $366.55 * *$ & 27 & .041 & .943 & .939 & .707 & .704 \\
\hline Three factors & $232.31 * *$ & 24 & .027 & .965 & .962 & .643 & .641 \\
\hline
\end{tabular}

a. Robust index, using Sattora-Bentler scaled $\chi^{2}$. the calculation of NFI were based on the tested and independent model chi-squares.

b. Parsimonious index using the parsimony ratio with degrees of freedom from the independent model (Mulaik et al., 1989).

\footnotetext{
${ }^{13} \mathrm{~N}=1664 ; * \mathrm{p}<.01 * * \mathrm{p}<.001$
} 
This is the version of the article accepted for publication in The International Journal of Human Resource Management published by Taylor and Francis doi:10.1080/09585190801953491

Accepted version downloaded from SOAS Research Online: http://eprints.soas.ac.uk/31984

\section{Table 5}

\section{Psychometric Properties of the Chosen Model for Each Scale ${ }^{14}$}

\begin{tabular}{|c|c|c|c|c|c|c|c|c|c|}
\hline \multirow[t]{2}{*}{ scale } & \multirow{2}{*}{$\begin{array}{c}\text { All } \\
\text { Loadi } \\
\text { ngs } \\
\text { above }\end{array}$} & \multicolumn{2}{|c|}{$\begin{array}{l}\text { Factor } 1 \\
\text { First Order }\end{array}$} & \multicolumn{2}{|c|}{$\begin{array}{l}\text { Factor } 2 \\
\text { First Order }\end{array}$} & \multicolumn{2}{|c|}{$\begin{array}{l}\text { Factor } 3 \\
\text { First Order }\end{array}$} & \multicolumn{2}{|c|}{$\begin{array}{l}\text { Second Order } \\
\text { Factor }\end{array}$} \\
\hline & & $\mathrm{Rel}^{\mathrm{a}}$ & V.E. & Rel. $^{\text {a }}$ & V.E $E^{b}$ & Rel. ${ }^{\mathbf{a}}$ & V.E. $\mathbf{b}^{\mathbf{b}}$ & Rel. a $^{\mathbf{a}}$ & V.E. $\mathbf{b}$ \\
\hline HPWP & .46 & .728 & .401 & .710 & .460 & .808 & .587 & .910 & .771 \\
\hline Mission & .62 & .915 & .547 & & & & & & \\
\hline Adaptability & .53 & .768 & .525 & .752 & .509 & .648 & .382 & .855 & .671 \\
\hline $\begin{array}{l}\text { Global } \\
\text { orientation }\end{array}$ & .70 & .812 & .592 & & & & & & \\
\hline Geocentrism & .49 & .721 & .397 & & & & & & \\
\hline Commitment & .48 & .915 & .553 & & & & & & \\
\hline
\end{tabular}

a. Rel.=composite reliability

b. V.E.=variance extracted.

\footnotetext{
${ }^{14} \mathrm{~N}=1664$
} 